\title{
ESPAÑOLES Y CIUDADANOS ANTE LA LEY EN LA CONSTITUCIÓN DE 1812
}

MANUEL JOSÉ TEROL BECERRA 


\section{SUMARIO}

1. LOS PROLEGÓMENOS: LA INSTALACIÓN DE LAS CORTES Y SU DECRETO DE 24 DE SEPTIEMBRE DE 1810. 2. LA IGUALDAD EN EL PROYECTO DE CONSTITUCIÓN. 2.1. La creación de la Comisión de Constitución y su postura inicial respecto a la igualdad. 2.2. El acuerdo de 10 de abril de 1811. 2.3. La propuesta definitiva sobre la igualdad. Los acuerdos de 7 y 8 de agosto de 1811. 3. LA ELABORACIÓN ESCALONADA DEL PROYECTO DE CONSTITUCIÓN, SUS FASES. 3.1. Las dos «primeras partes» del Proyecto de Constitución. Su debate en el Pleno. 3.1.1. La discusión sobre el art. 5. 3.1.2. La polémica sobre las castas. 3.2. La segunda entrega del Discurso Preliminar y del Proyecto de Constitución. 3.2.1. La igualdad ante la ley en el Discurso Preliminar. 3.2.2. Unidad de jurisdicción y voluntad codificadora en el Proyecto de Constitución. 4. LA SOLUCIÓN CONSTITUCIONALMENTE ADOPTADA. 4.1. Esclavos, libertos, hombres libres y ciudadanos. 4.2. La igualdad ante la ley. 4.2.1. Acerca de la ley y de su conceptuación constitucional. 4.2.2. Igualdad de derechos e igualdad ante la ley. 4.2.3. Referencia al instituto de las infracciones de la Constitución. 4.2.4. Codificación y unidad jurisdiccional. 4.2.5. Los deberes de los españoles. En especial, la obligación de contribuir. 4.3. El Proyecto de Código Civil de 1821. 


\title{
ESPAÑOLES Y CIUDADANOS ANTE LA LEY EN LA CONSTITUCIÓN DE 1812
}

\author{
POR \\ MANUEL JOSÉ TEROL BECERRA \\ Catedrático de Derecho Constitucional \\ Universidad de Sevilla
}

\section{LOS PROLEGÓMENOS: LA INSTALACIÓN DE LAS CORTES Y SU DECRETO DE 24 DE SEPTIEMBRE DE 1810}

Antes de promulgarse la Constitución de 1812 e incluso de que decidieran las Cortes elaborarla, adoptaron el acuerdo, tempranamente impregnado de cualidades constitucionales, que significó el Decreto de 24 de septiembre de 1810. No es que la idea de dotar a España de una Constitución surgiese por primera vez en las Cortes de Cádiz. Fue enunciada con anterioridad en el contexto de los sucesos ciertamente convulsos que se dieron en España durante la guerra contra el ejército napoleónico. El apresamiento de Fernando VII en Bayona provocará un sentimiento de reacción nacional frente a Napoleón que culminará en una guerra contra su ejército. Por parte española intentarán asumir la dirección de la contienda las llamadas «juntas patrióticas», nacidas espontáneamente a lo largo del territorio con ese fin. Tales juntas, por efecto de la intensa relación que mantuvieron desde el primer momento y movidas del claro deseo de subvenir unificadamente a las necesidades de la guerra, crearon un órgano superior que ejerciese su dirección en toda España y lograr así la ansiada unidad de acción. Con tal fin, se reunirían en Aranjuez los diputados de las juntas provinciales y 
constituyeron, el 25 de septiembre de 1808, la Junta Suprema Central Gubernativa de España e Indias. Esta acordó el 22 de mayo de 1809 efectuar un llamamiento a las Cortes, creando al efecto una comisión que, con ese nombre, desplegó una intensa actividad centrada en el modo en que debían éstas congregarse o reunirse y en preparar los principales puntos de reforma y mejora que convenía proponer en punto a la gobernación del país ${ }^{1}$. Dicha Comisión creó a su vez un total de siete juntas y, atendiendo al relato que ofrece al respecto María Cristina Diz-Lois, en el seno de una de ellas, la de «Constitución y legislación», se debatirá sobre la conveniencia de que el pueblo español se diese una Constitución ${ }^{2}$. De acuerdo con tales antecedentes difícilmente podría sostenerse, como decimos, que esa idea fuese original de las Cortes. Máxime cuando, según nos refiere además la citada autora, desde la fecha en que éstas quedaron oficialmente reunidas y dieron comienzo sus sesiones los periódicos de Cádiz fueron creando un estado de opinión en su favor ${ }^{3}$. Aunque resulta enormemente difícil saber si la prensa infundió a las Cortes la idea constitucional o fue a la inversa, teniendo en cuenta la naturaleza de las medidas que adoptaron éstas —el mismo día de su instalación- en el Decreto de 24 de septiembre de 1810.

El referido Decreto, carente de forma articulada, comenzaba con una declaración de principios mancomunadamente asumida por los miembros de la Asamblea, aparentemente dirigida a dejar constancia de que esta sesión constitutiva de las Cortes tenía para el órgano una dimensión fundacional cuya legitimación convenía explicar:

«Los Diputados que componen este Congreso, y que representan a la Nación española, se declaran legítimamente constituidos en Cortes generales y extraordinarias, y que reside en ellas la soberanía nacional».

La explicación no hubiese hecho falta de responder la reunión de Cortes a los criterios que hasta entonces habían sido tradicionales. Pero no era así, como tampoco lo eran los principios que proclamaba el Decreto, completamente distintos de aquellos en que se había venido sustentando el antiguo régimen. Ya en su momento subrayaría Sánchez Agesta el carácter revolucionario de primer orden que tenían las manifestaciones iniciales del Decreto por lo que significaban de

${ }^{1}$ Por María Cristina Diz-Lois sabemos que la Comisión de Cortes a que nos referimos fue creada por un Decreto de 8 de junio de 1809. Cfr. su «estudio preliminar» a las Actas de la Comisión de Constitución (1811-1813) (Coordinador Federico Suárez), Madrid, Instituto de Estudios Políticos, 1976, p. 41.

${ }^{2}$ Cfr. Ibíd. pp. 43 a 45.

3 Cfr. Ibíd. p. 45. 
ruptura con el antiguo régimen ${ }^{4}$, y no puede decirse que le faltara la razón a la vista de la proclamación que en él se hacía de la soberanía nacional. Es más, atendiendo a las restantes afirmaciones que contenía el Decreto, no cabe sino calificar de acertada la opinión emitida por el citado autor. Efectivamente, en lo que aquí interesa conviene destacar que las primeras manifestaciones del documento anteriormente citadas eran seguidas de otra que revela cual era el sentir de las Cortes generales y extraordinarias de la nación española: actuar «conformes en un todo con la voluntad general». Formulada en un contexto de protesta solemne contra las usurpaciones de Napoleón y en lo que tiene de reivindicación de la nación española a darse sus leyes fundamentales, esta última declaración ${ }^{5}$ precedía a una tercera de no menor importancia:

«No conviniendo queden reunidos el Poder legislativo, el executivo y judiciario, declaran las Cortes generales y extraordinarias que se reservan el exercicio del Poder legislativo en toda su extensión».

Tal invocación a la doctrina de la separación de poderes que, tras reservar a las Cortes el ejercicio del legislativo, desarrollaba luego el Decreto, complementaba, claro está, a la proclamación de la soberanía nacional que había efectuado anteriormente haciéndola residir en las Cortes, como no podía ser de otro modo dada la condición de representantes de la Nación española que para sí reclamaban sus miembros, los Diputados. Dicha circunstancia permitía, por añadidura, asegurar al colegio un vínculo con la voluntad general que necesariamente habría de transmitir a sus acuerdos. Así lo decía el Decreto que, no en balde, reputaba a las Cortes conformes con la voluntad general y lo que a continuación en él se establecía expresión de la misma.

En cuanto sustituía al monarca por la nación como titular de la soberanía y especificaba que su ejercicio estaría presidido por el principio de separación de poderes, con lo que eso significaba de garantía para los ciudadanos, puede decirse que el Decreto de 24 de septiembre de 1810 adelantaba la idea constitucional. Nada más lejos de nuestra intención que pretender identificar el referido Decreto con una auténtica Constitución. Esta vendrá después pero no cabe duda de que

${ }^{4}$ Cfr. Historia del constitucionalismo español, Madrid, Instituto de Estudios Políticos, 1974, p. 61.

${ }^{5}$ Cfr. Ibíd. p. 61. El contexto en que se produjo, atinadamente enjuiciado por Sánchez Agesta, era el siguiente: «Las Cortes generales y extraordinarias de la Nación española, congregadas en la Real isla de León, conformes en todo con la voluntad general, pronunciada del modo más enérgico y patente, reconocen, proclaman y juran de nuevo por su único y legítimo Rey al Señor Don Fernando VII de Borbón, y declaran nula, de ningún valor ni efecto la cesión de la Corona que se dice hecha en favor de Napoleón, no sólo por la violencia que intervino en aquellos actos injustos e ilegales, sino principalmente por faltarle el consentimiento de la Nación». 
propiciada por aquél, cuyas previsiones, en lo que revelan tener de intento por racionalizar la estructura básica de la nueva forma de organización política que pretendía implantarse, anticipaban la noción de Constitución aunque sólo fuera abocetadamente. Desde este punto de vista, su paralelismo con la Declaración de los Derechos del Hombre y del Ciudadano de 1789 es tan notable que admite ser calificado, como ella, de Constitución de urgencia; sin perjuicio de lo cual no debe ignorarse que, a diferencia de la citada declaración francesa, el Decreto de las Cortes carecía de una proclamación de derechos y, por tanto, de pronunciamiento alguno sobre la igualdad.

\section{LA IGUALDAD EN EL PROYECTO DE CONSTITUCIÓN}

Tampoco la Constitución de 1812 contenía una específica declaración de derechos: Bien es verdad que se afanaba en construir una esfera de libertad individual a salvo de la intervención de los poderes públicos y en torno al reconocimiento en su art. 4 de la libertad y del derecho de propiedad. A este respecto describía el art. 287 de qué modo debía procederse a la detención gubernativa, con lo que eso significaba de aspiración por garantizar la libertad deambulatoria; definía el art. 294 en qué supuestos estaba garantizado el embargo de bienes, cuya confiscación prohibía el art. 304 en todo caso; y consagraba el art. 306 la inviolabilidad del domicilio. Además de las referidas disposiciones, más o menos implicadas en señalizar los linderos de la libertad civil y del derecho de propiedad, deben mencionarse otras cuyas previsiones, a diferencia de las anteriores, carecían de un denominador común alrededor del cual agruparlas, pero no por eso eran menos reveladoras del nuevo estado de cosas que se buscaba implantar. En este sentido, atendía la Constitución en el art. 303 a la protección de la integridad física mediante la prohibición del uso de tormentos. También reconocía a los españoles en su art. 371 la libertad de escribir, imprimir y publicar sus ideas políticas, del mismo modo que a los ciudadanos los derechos al sufragio y de acceso a los empleos públicos, ya veremos en qué disposiciones y cómo, e incluso, a tenor de lo previsto en el Título IX, asumía el Estado ciertas obligaciones en materia de instrucción pública.

La somera descripción del modo en que se ocupó la Constitución de 1812 de los derechos que consagraba ratifica nuestra afirmación inicial. Nada más alejado de una declaración de derechos al estilo de las que incluían las constituciones francesas de 1791 y 1795 que su enumeración dispersa a lo largo del texto constitucional, sin destinar específicamente a esta finalidad ninguno de sus títulos o capítulos, según decimos que hacía la española de 1812. Lo más parecido 
con una declaración de derechos, aunque sólo un tanto forzadamente podía considerarse como tal, se resumía en la dicción literal de su art. 4:

«La Nación española está obligada a conservar y proteger por leyes sabias y justas la libertad civil, la propiedad y los demás derechos legítimos de todos los individuos que la componen».

A fuer de sucinto no mencionaba el artículo sino la libertad civil y el derecho de propiedad antes de efectuar un llamamiento en favor de otros derechos innominados. Su lacónico enunciado nos disuade de intentar equipararlo al del art. 122 de la Constitución francesa de 1793 con el que sí guarda alguna semejanza no es tan intensa que mueva a pasar por alto las enormes diferencias que existen entre ambas disposiciones. En efecto, es patente la distancia que separa a la fórmula usada en el art. 4 de la Constitución de 1812 con la empleada en el art. 122 de la Constitución francesa de 1793, no ya porque esta última disposición pareciese pretender garantizar por sí sola los derechos relacionados en la declaración formal que antecedía a la Constitución propiamente dicha — en lugar de reproducirla, más o menos fielmente, como hicieron con ese mismo objetivo garantista las constituciones de 1791 y 1795 con las declaraciones que les precedían-, sino también y principalmente por la completa enumeración de derechos que hacía y que se echa de menos en el caso español. La Constitución de 1812 ni siquiera se detenía a ofrecer una simple lista de derechos que, a falta de una declaración más detallada, hiciese sus veces, y pudiera considerarse una peculiar manera española de afrontar este asunto inspirada en el art. 122 de la Constitución francesa de 1793. En cambio, sí dedicó la Constitución de 1812 una serie de artículos a enunciar ciertos deberes y obligaciones de los españoles a los que luego prestaremos la atención que merecen, pues interesa destacar ahora que si omitió todo tipo de declaración de derechos no fue por olvido, sino por expreso deseo de las Cortes generales y extraordinarias.

\subsection{La creación de la Comisión de Constitución y su postura inicial respecto a la igualdad}

Desde que el 24 de septiembre de 1810 celebraron las Cortes su sesión constitutiva transcurrirían más de dos meses hasta que adoptaron la primera medida relacionada con la redacción de una futura Constitución. Consistió ésta en crear una Comisión que propusiera al plenario el oportuno proyecto, en el cual pensaron inicialmente los miembros de dicha Comisión incluir una declaración de derechos, aunque luego abandonaron la idea y en el Pleno nadie volvería a enunciarla. 
Según sostiene Diz-Lois, quien sigue de cerca el relato que ofrece al respecto Lorenzo de Villanueva en su libro Mi viaje a las Cortes, esa primera providencia relacionada con la elaboración de una Constitución, estuvo precedida de un amplio debate que tuvo lugar en la sesión de 8 de diciembre de 1810 y en la que varios diputados tuvieron ocasión de formular propuestas en ese mismo sentido. Según el citado autor la iniciativa de Mejía Lequerica instando a las Cortes a no disolverse sin haber hecho antes una Constitución no fue desoída por la Cámara. Algunos de sus miembros aprovecharon la oportunidad para defender la necesidad de redactar una Constitución. Uno de ellos habría sido Muñoz Torrero quien al parecer solicitó de las Cortes que invitasen a «los sabios nacionales y extranjeros a que presten sus luces para el acierto de las Cortes en este negocio, siendo de interés común no sólo nuestro, sino de las potencias extranjeras que tengamos una Constitución». Con tal fin habría llegado a proponer además a las Cortes que, mediante decreto, se ofreciese un premio al autor de la mejor Memoria sobre la Constitución política de la Monarquía ${ }^{6}$. No entraremos en consideraciones acerca de lo insólito del argumento sobre la necesidad de contar con una Constitución por imperativos no sólo de interés nacional, sino también de índole internacional. Nos interesa en cambio subrayar que la propuesta de $\mathrm{Mu}-$ ñoz Torrero hizo recordar a otro diputado que ya la Junta Central, a través de su Comisión de Cortes, había llegado a reunir más de ciento cincuenta memorias a propósito de una futura Constitución.

Con independencia de cuales pudieran haber sido los pormenores del debate resolvieron las Cortes en su sesión de 8 de diciembre encargar a quienes habían realizado las propuestas más concretas que en la jornada siguiente las formulasen por escrito. De ahí que el 9 acordaran nombrar «una comisión de ocho individuos, cuando menos, para que teniendo presentes los trabajos preparados por la Junta Central proponga un proyecto de Constitución política de la Monarquía» ${ }^{7}$. Todavía el 12 de diciembre volverán las Cortes sobre este asunto y, a modo de respuesta a lo que había solicitado Muñoz Torrero el día 8, encomendaron a dicha Comisión que, en el plazo de ocho días, confeccionase un decreto invitando a los sabios a la formación de una Memoria sobre la Constitución ${ }^{8}$.

La Comisión no llegó a celebrar su sesión constitutiva hasta el 2 de marzo de 1811, pero ese mismo día procedió a cumplimentar los acuerdos del plenario del 9 y 12 de diciembre. De acuerdo con ellos, decidió recoger «todas las memorias

${ }^{6}$ Una exposición detallada de los hechos que hemos narrado resumidamente es la que ofrece Diz-Lois en su «estudio preliminar» a las Actas de la Comisión de Constitución, cit. pp. 16 a 18.

7 Cfr. Ibíd. p. 19.

${ }^{8}$ Cfr. Ibíd. 
y proyectos que se trabajaron sobre la Constitución en tiempo de la Junta Central y demás que, por otras personas, se hubiesen presentado o presentasen y que se tendrían a la vista»?.

Nos parece una exageración que la Comisión de Cortes hubiese logrado reunir más de ciento cincuenta memorias sobre la Constitución, se supone que gracias a la actividad desarrollada a su vez por la Junta de Constitución y legislación ${ }^{10}$, y aun aceptando que su número fuese tan elevado cuesta creer que se conservasen todas y no se perdiese ninguna en el accidentado traslado de la Junta Central de Sevilla a Cádiz. Fueran las que fuesen la Comisión de Constitución dispuso pronto de ellas, reflejándolo así el acta de la segunda sesión que celebró el día 6 de marzo, donde consta que «se presentaron las Memorias que en íntegro o en extracto, se conservan de las trabajadas en tiempo de la Junta Central sobre materias análogas, y se leyeron sus epígrafes, quedando acordado que se tendrían a la vista ${ }^{11}$.

En cuanto a las otras memorias a que se refiere la resolución adoptada por la Comisión de Constitución el mismo día en que se reunió por primera vez, esto es, «las demás que por otras personas se hubiesen presentado o presentaren», es de presumir que se conocería muy pronto el acuerdo de 12 de diciembre de 1810 que, a instancias de Muñoz Torrero, tomaron las Cortes de invitar a los sabios a la formación de memorias sobre la Constitución y que se presentara alguna entre esa fecha y la del 2 de marzo de 1811 en que tuvo lugar la primera sesión de la Comisión de Constitución. A esa circunstancia estaría haciendo referencia la fórmula usada en la invitación que había de hacerse formalmente y le correspondía realizar a la Comisión: «las demás que (...) se hubiesen presentado o presentaren». Según Diz-Lois la iniciativa de las Cortes obtuvo respuesta pues llegaron a presentarse algunas memorias de las cuales se desconoce todo excepto que existieron ${ }^{12}$. Nos apartaría de-

9 Cfr. Actas de la Comisión de Constitución, cit. p. 72. El hecho de que dos de los doce miembros con que inicialmente contó la Comisión de Constitución, Agustín de Argüelles y José Pablo Valiente, lo hubiesen sido también de la Junta de Constitución y Legislación, contribuyó seguramente a la pronta realización de este encargo del Pleno y, muy probablemente, favoreció además la posterior ejecución de la tarea, en cierto modo continuista, que se le encomendaba, sin condicionar por eso, en absoluto, la dimensión innovadora y hasta revolucionaria que forzosamente habría de tener su decisión sobre el Proyecto de Constitución. Por resolución que la propia Comisión adoptó en su sesión de 12 de marzo, se acordó invitar a integrarse en la misma a Ranz de Romanillos y a dos diputados más «de los propietarios de América», pasando, en consecuencia, a contar con 16 miembros. Cfr. Actas de la Comisión de Constitución, cit. p. 75.

${ }^{10}$ Diz-Lois habla de dos que fueron objeto de especial atención por la Junta de Constitución y Legislación. Cfr. su «estudio preliminar» a las Actas de la Comisión de Constitución, cit. pp. 44 y 45.

${ }_{11}$ Cfr. Actas de la Comisión de Constitución, cit. p. 73.

${ }^{12}$ Cfr. su «estudio preliminar» a las Actas de la Comisión de Constitución, cit. p. 19. 
masiado de nuestro objetivo indagar más sobre este asunto. Renunciamos a conocer cual pudo ser su influencia sobre el proyecto de Constitución, nos basta con saber que la Comisión dispuso de ellas así como de las que se conservaban de las reunidas por la Junta Central. Tampoco nos detendremos a examinar cual pudo haber sido el grado de influencia que tuvieron unas y otras memorias en el Proyecto de Constitución, máxime teniendo en cuenta que, probablemente debido a su considerable número, optó la Comisión por simplificar las cosas y centrar su trabajo en torno a un texto que hiciese las veces de anteproyecto. Por las razones que fueran se decidió que fuese uno que estaba en posesión de Ranz de Romanillos a quien, después de visitarle reiterada e infructuosamente varios miembros de la Comisión con objeto de que les facilitase el proyecto, se terminó invitando a sumarse a la misma ${ }^{13}$ presumiblemente en los términos del acuerdo de 2 de marzo, esto es, con voz y voto ${ }^{14}$ - dándole algún tiempo para que concluyese de copiar el documento en cuestión ${ }^{15}$. De manera que sólo cuando, por fin el 16 de marzo, se presentó con él Ranz de Romanillos en la Comisión puede decirse que inició ésta sus tareas relacionadas con la redacción de un proyecto de Constitución.

Todavía se dedicó esta sesión y las dos siguientes a que Ranz de Romanillos leyese «el proyecto de Constitución y el catálogo trabajado por él mismo de las leyes de diferentes Códigos nacionales que tratan de puntos constitucionales ${ }^{16}$, comenzando verdaderamente a discutirse al final de la sesión celebrada el 23 de marzo, donde «se hicieron algunas reflexiones generales sobre los principios que convendría establecer como preliminares en la Constitución, y quedó el señor Torrero en traer para la primera sesión un apunte de sus ideas» ${ }^{17}$.

Así fue, en la sesión siguiente, del 25 de marzo, presentó Muñoz Torrero seis proposiciones que, con otras varias de Espiga, se leyeron y fueron objeto de algún comentario. Al parecer, sólo las del primero despertaron el interés de la Comisión, al menos en torno a ellas giró la discusión que tuvieron sus miembros en la sesión del día 27, en la que determinaron finalmente encabezar la futura Constitución con tales proposiciones o principios y decidieron, en consecuencia, aprobar los tres primeros artículos del proyecto que, con la misma redacción, terminarían convirtiéndose en los tres primeros de la Constitución. No olvidaron en

13 De tales visitas y de su resultado se trató en las sesiones de 8 y 12 de marzo, según consta en las actas correspondientes. Cfr. Actas de la Comisión de Constitución, cit. pp. 74 y 75.

${ }^{14}$ Cfr. Ibíd. p. 73.

15 Cfr. Ibíd. p. 75.

${ }^{16}$ Cfr. las actas correspondientes a los días 16, 20 y 23 de marzo, especialmente la primera de donde hemos extraído la cita. Cfr. Ibíd. pp. 75 y 76.

17 Cfr. Ibíd. p. 76. 
esta misma sesión dotar al proyecto de un orden sistemático y, con tal finalidad, crearon un epígrafe introductorio al que denominaron «Principios generales» y en el que previsoramente incluyeron un capítulo primero que, con el nombre «De la nación española», acogía a esos tres artículos ${ }^{18}$.

En la sesión del 29 se añadió otro, idéntico al que luego fue aprobado como art. 13 de la Constitución, y uno más de análoga factura a la del que terminó convirtiéndose en el art. 4 de la Constitución, pues, a diferencia de éste, no aludía a ningún derecho ${ }^{19}$. A enumerarlos decidió la Comisión destinar el artículo siguiente, en donde tan sólo se mencionaba la seguridad, la libertad y la propiedad, después de discutir sobre si debía incluirse en él o no la igualdad y de resolver dedicar un artículo, más adelante, a su exclusivo tratamiento, pues acordó la Comisión definir antes cada uno de aquellos derechos, y la seguridad, la libertad y la propiedad fueron, por consiguiente, sucesivamente definidas en sendos artículos — del modo que se verá más adelante cuando nos ocupemos de la sesión del 10 de abril-, sin que conste en el acta correspondiente a la sesión que venimos comentando haberse producido el menor debate previo acerca de sus correspondientes enunciados. Sin duda que existió, pero el hecho de que no se reflejase en el acta es revelador de lo maduras que estaban en la Comisión las ideas en torno al respectivo significado y alcance de tales derechos. No sucedía así con la igualdad, pues consta en el acta que, cuando ese día 29, a la Comisión le tocó pronunciarse sobre la misma, se originó entre sus miembros un debate del que ignoramos cómo se desarrolló, pero no que concluyó con la aprobación del artículo que habían prometido dedicarle, el cual respondía al siguiente dictado:

Art 10.- «En el libre uso y goce de estos derechos todos deben ser iguales, y de este modo la igualdad es también uno de ellos» ${ }^{20}$.

Los referidos planteamientos iniciales sobre la igualdad no pasaron de ser una forma de aproximarse a su tratamiento. Muy pronto serían revisados por la Comisión que, en su sesión del 5 de abril, decidió que la igualdad fuese «expresamente comprendida entre los derechos de los españoles en el artículo que los enumera». De acuerdo con ello debía modificarse la proyectada disposición para que acogiese en el listado de derechos a que se reducía su redacción, la mención a la igualdad, y así lo hizo aprovechándose la ocasión para alterar el orden en que se había decidido mencionarlos en la sesión de 29 de marzo. En definitiva, se acordó que tales derechos fueran la libertad, la seguridad, la propiedad y la igualdad.

${ }_{18}$ Cfr. Ibíd. cit. p. 77.

19 El enunciado de la disposición propuesta era el siguiente: Art. 5.- La Nación está obligada a proteger y conservar a sus individuos todos sus derechos. Cfr. Cfr. Ibíd. pp. 78 y 79.

${ }^{20}$ Cfr. Ibíd. pp. 78 y 79. 
A la Comisión no se le escapó que su decisión de incluir a esta última en la relación acarreaba una consecuencia lógica de orden inmediata. Procedía entonces, como se había resuelto hacer con los restantes derechos, que se le dedicase un artículo del proyecto de Constitución a definir la igualdad. Sobre este asunto se discutió largamente, determinándose finalmente ofrecer una definición que nació aquejada de la provisionalidad por los términos en que se acordó: «a reserva de rectificarla si pareciese y se pudiese adoptar un concepto mejor». Dicha definición era la siguiente:

«La igualdad consiste en que no haya diferencia alguna entre los individuos que componen la Nación en el uso y goce de sus derechos, ni en la distribución de premios y aplicación de castigos $»^{21}$.

\subsection{El acuerdo de 10 de abril de 1811}

No será ésta la última palabra de la Comisión acerca de la igualdad. En la sesión de 10 de abril volvió a debatir sobre la misma para concluir modificando su recién citada definición de unos días antes. Interesa destacar que el acuerdo correspondiente fue enunciado en el marco de otro esclarecedor de la finalidad perseguida con los trabajos que hasta esa fecha había realizado. Nos referimos a la decisión de incluir en el Título I un Capítulo II con la idea de que acogiese lo que significativamente anunciaba su rúbrica: «De los españoles, sus derechos y obligaciones». En él era recogida la declaración de derechos a que más arriba nos hemos referido, un artículo primero, parecido al que finalmente se convertiría en art. 5 de la Constitución, dedicado a definir quienes serían considerados españoles y una relación de deberes por cuya versión constitucionalmente sancionada nos interesaremos luego. Ahora juzgamos oportuno situar en su contexto la segunda definición de igualdad que ofreció la Comisión. En otras palabras, la enorme importancia que concedemos a la proyectada declaración de derechos en que se integraba - reiterante por cierto de los enunciados que se acordó dar a la seguridad, la libertad y la propiedad en la sesión de 29 de marzo- nos anima a reproducirla íntegramente:

\section{«CAPITULO II: DE LOS ESPAÑOLES, SUS DERECHOS Y OBLIGA- CIONES}

Artículo $1^{\circ}$.- Son españoles: $1^{\circ}$ ) todos los hombres libres nacidos y avecindados en los dominios de España, y los hijos de éstos; $2^{\circ}$ ) los extranjeros que hayan

${ }^{21}$ Cfr. Ibíd. p. 81. 
obtenido carta de naturaleza; $3^{\circ}$ ) los que sin ella lleven 10 años de vecindad ganada según la ley en cualquier pueblo de la Monarquía; $4^{\circ}$ ) los hijos de unos y otros que hayan nacido en territorio español y tengan ocupación conocida en el pueblo de su residencia; y $5^{\circ}$ ) los libertos desde que adquieran su libertad en España.

Artículo $2^{\circ}$.- Los derechos de los españoles son la libertad, la seguridad, la propiedad y la igualdad.

Artículo $3^{\circ}$.- La libertad consiste en poder hacer todo lo que no perjudica a la sociedad, ni ofende a los derechos de otro.

Artículo $4^{\circ}$.- La seguridad consiste en ser cada individuo protegido por la fuerza pública contra la ofensa que se haga a su persona o a sus derechos.

Artículo $5^{\circ}$.- La propiedad es el derecho de gozar y disponer libremente de sus bienes y del fruto de su talento, de su trabajo y de su industria.

Artículo $6^{\circ} .-$ La igualdad consiste en que no haya diferencia alguna entre los individuos que componen la Nación en el uso y goce de sus derechos» ${ }^{22}$.

\subsection{La propuesta definitiva sobre la igualdad. Los acuerdos de 7 y 8 de agosto de 1811}

Tan prometedoras expectativas como alentaba este acuerdo de 10 de abril terminarían, sin embargo, malográndose. A la Comisión no acabó por satisfacerle y en el último momento, pocos días antes de presentar a las Cortes las dos primeras partes de su proyecto de Constitución, decidió modificar el referido acuerdo por los motivos que se indicaron en la sesión correspondiente al 7 de agosto:

«Se propusieron diferentes pensamientos dirigidos a dar otro aire a los artículos que tratan de los derechos de los españoles, por parecer a algunos de los señores de la Comisión que será más original y sencillo enunciar las cosas sin hacer enumeración de los derechos. Y discutido largamente quedó aprobado o acordado por la mayoría, que a continuación del art. $5^{\circ}$ del Capítulo $1^{\circ}$ del Título I se indicasen o expresasen las definiciones de los tres primeros derechos, y oblicuamente se insinuase el cuarto. Quedó la fracción de Comisión encargada de extender los términos del capítulo, debiendo resultar de esta variación la conveniente en los epígrafes ${ }^{23}$.

${ }^{22}$ Cfr. Ibíd. pp. 81 y 82.

${ }^{23}$ Cfr. Ibíd. p. 165. 
No indagaremos respecto a qué pretendía la Comisión mostrarse original, aunque no es descabellado pensar que buscase apartarse del modelo que le ofrecían las constituciones francesas de 1791, 1793 y 1795, precedidas de sendas declaraciones de derechos. En todo caso, cumplimentó inmediatamente la resolución que había adoptado al efecto, pues según consta en el acta de la sesión que celebró al día siguiente, el 8 de agosto, «presentó la fracción el artículo en que se habla de los derechos y quedó acordado en los términos que contiene la copia original que conserva el secretario de la Comisión y sirve para la redacción que se está haciendo del proyecto» ${ }^{24}$.

En resumidas cuentas, resuelta como estaba a prescindir de una declaración formal de derechos, la Comisión suprimió de su proyecto de Constitución la que anteriormente había acordado incluir en él, aunque sin renunciar por eso a dotarlo de un reconocimiento expreso de derechos civiles en favor de los españoles. A su tratamiento decidió primero dedicar un sólo artículo del proyecto, cuyo dictado concluiría refundiendo en última instancia con el de su art. 5 que, en consecuencia, obtuvo la siguiente redacción:

«La Nación está obligada a conservar y proteger por leyes sabias y justas la libertad civil, la propiedad y los demás derechos legítimos de los individuos que la componen $»^{25}$.

La Comisión tendría la oportunidad de manifestarse acerca del inciso final del recién citado artículo en el fragmento de Discurso Preliminar que remitió a las Cortes acompañando a las «dos primeras partes» del Proyecto de Constitución, entre cuyas previsiones se integraba aquella disposición. En efecto, en esta primera entrega del Discurso Preliminar pueden leerse ciertas afirmaciones que sólo pueden estar referidas a ese inciso final y que juzgamos oportuno reproducir por lo que ilustran respecto al significado que le atribuía la Comisión:

«(...) la experiencia acredita y aconseja la prudencia que no se pierda jamás de vista cuanto conviene a la salud y bienestar de la Nación no dejarla caer en el fatal olvido de sus derechos, del cual han tomado origen los males que la han conducido a las puertas de la muerte».

La clara, sencilla, pero solemne declaración de lo que le corresponde como Nación libre y soberana, presentando a cada paso a los que tengan la dicha de dirigirla bajo los auspicios del Sr. D. Fernando VII y sus legítimos sucesores los derechos de la Nación española, les indicará con toda claridad de qué modo han de

${ }^{24}$ Cfr. Ibíd. p. 166.

${ }^{25}$ Cfr. la versión inicial del mismo en la nota 124. 
usar de la autoridad que la Constitución y el Monarca confíen a su cuidado. En el ejercicio del respectivo ministerio que cada funcionario desempeñe, no podrá desentenderse de tener fija la vista en la inmutable regla de una declaración tan augusta, en donde ha de leer sus tremendas e inviolables obligaciones; los españoles de todas clases, de todas edades y de todas condiciones sabrán lo que son y lo que es preciso que sean para ser honrados y respetados de los propios y extraños. No es menos importante expresar las obligaciones de los españoles para con la Nación» ${ }^{26}$.

\section{LA ELABORACIÓN ESCALONADA DEL PROYECTO DE CONSTITUCIÓN, SUS FASES}

Considerando que ya hemos adelantado algo relativo a como se gestaron el Discurso Preliminar y el Proyecto de Constitución, quizá convenga aclarar del todo este asunto antes de relatar qué acogida tuvieron en el Pleno las propuestas de la Comisión. A este respecto debe tenerse presente que las Cortes recibieron de aquella tres sucesivas entregas que totalizaban en conjunto el Proyecto de Constitución. Por la razón que fuera no esperó la Comisión a tenerlo redactado de principio a fin para remitírselo al Pleno, sino que optó por enviárselo de manera fraccionada, a medida que concluía alguna de sus partes, desiguales en extensión aunque homogéneas en sus contenidos. Tres recibieron en total las Cortes, como decimos, respectivamente prologadas de un fragmento de Discurso Preliminar. Hace algún tiempo que tanto Diz-Lois como Sánchez Agesta repararon en dicha circunstancia y afirmaron, por ese orden, que el último de los documentos citados no se redactó de una sola vez, sino que se elaboró en tres tiempos ${ }^{27}$. Basta con acudir a las actas de la Comisión y al Diario de Sesiones para comprobar que sus apreciaciones son correctas.

Según reseñó el secretario de la Comisión en una nota a las actas fechada el 18 de agosto, se firmó, no aclara exactamente cuándo, «el Discurso y la Constitución por todos los señores de la Comisión, excepto el señor Valiente» ${ }^{28}$. En realidad debe entenderse que suscribieron el trabajo realizado hasta esa fecha,

${ }^{26}$ Cfr. Diego Sevilla Andrés: Constituciones y otras leyes y proyectos políticos de España, Vol. I, Madrid, Editora Nacional, 1969, p. 124.

27 Diz-Lois en su «estudio preliminar» a las Actas de la Comisión de Constitución, cit. p. 65. Luis Sánchez Agesta, confirmó este dato en su introducción al Discurso Preliminar a la Constitución de 1812, Madrid, C.E.C., 1981, p. 20.

${ }^{28}$ Cfr. Actas de la Comisión de Constitución, cit. p. 171. 
dada la información que nos proporcionan al respecto tanto las actas de la Comisión, como el Diario de Sesiones de las Cortes. Pues en el acta de la sesión que celebró la Comisión dos días antes tan sólo de diligenciar su secretario haberse verificado la firma en cuestión, esto es, en el acta correspondiente al 16 de agosto, consta haber acordado sus miembros «que en la mañana del día siguiente anunciaría el secretario Pérez de Castro, en nombre de la Comisión, a las Cortes hallarse concluida la parte de la obra que debía presentarse» ${ }^{29}$. Mientras el Diario de Sesiones del 18 de agosto confirma que ese día en las Cortes «leyó el Sr. Argüelles el Discurso Preliminar de la Constitución española y el Sr. Pérez de Castro las dos primeras partes del proyecto de la misma ${ }^{30}$. Encerraban éstas los que terminarían convirtiéndose en los cuatro primeros títulos de la Constitución, así lo evidencian también las actas de la Comisión y el Diario de Sesiones. Poco después de efectuarse en el Pleno dicha lectura retornaría la Comisión a su quehacer, como lo testimonia el acta de la sesión que celebró el 23 de agosto, no menos reveladora, por el lugar en que dice haberse reanudado los trabajos, de en donde habían quedado interrumpidos, y de qué parte del Proyecto habría conocido el Pleno en primer lugar. Por el acta del 23 de agosto sabemos con certeza que ese día «se reunió de nuevo la Comisión para continuar sus tareas en la formación de lo que resta del Proyecto. La fracción de Comisión presentó el epígrafe del Título V que ha de tratar del Poder Judicial» ${ }^{31}$. Esta parte del Proyecto y la correlativa del Discurso fueron aprobadas por la Comisión el 5 de noviembre ${ }^{32}$. Argüelles se lo comunicó ese mismo día al Congreso y con su beneplácito leyó al día siguiente en el Pleno «el Discurso Preliminar a la tercera parte del Proyecto de la misma [Constitución] relativa al poder judicial, que a continuación leyó el Sr. Pérez de Castro» ${ }^{33}$. Ante tan nítida delimitación del contenido correspondiente a dicha «tercera parte» del Proyecto como efectuaron la Comisión y el Pleno, huelga todo comentario, igualmente ocioso con relación a la última parte del Proyecto por la facilidad con que se identifican sus enunciados por referencia a los

${ }^{29}$ Cfr. Ibíd.

30 Diario de Sesiones de las Cortes Generales Extraordinarias. Núm. 320, de 18 de agosto de 1811 , p. 1651. El subrayado es nuestro.

31 Cfr. Actas de la Comisión de Constitución, cit. p. 171.

32 Según consta en el acta correspondiente al 5 de noviembre: «Se reunió la Comisión para oír la lectura de la parte del Discurso preliminar y del Título del proyecto de Constitución que es relativo a la potestad judicial. Se aprobó uno y otro; se hizo la ligera variación de una que otra palabra en el Discurso; firmaron todos los señores de la Comisión que se hallaron presentes, y quedó entendido que el siguiente día se haría la pública lectura en las Cortes, como estaba ya anunciado». Cfr. Actas de la Comisión de Constitución, cit. p. 199.

33 D.S.C.G.E., núm. 400, de 6 de noviembre de 1811, p. 2219. 
de esa «tercera parte». Por fin el 24 de diciembre «se reunió la Comisión para oír la parte del Discurso Preliminar y la de los artículos que componen esta última parte del Proyecto de Constitución; y hecha quedó acordado que se daría cuenta a las Cortes» ${ }^{34}$. Pérez de Castro se ocupó esa misma jornada de anunciarlo ${ }^{35}$ y dos después, el 26 de diciembre, «se procedió a la lectura de la última parte del Proyecto de Constitución» en el Pleno, corriendo una vez más a cargo de Argüelles la del Discurso Preliminar y de Pérez de Castro la del Proyecto ${ }^{36}$.

\subsection{Las dos «primeras partes» del Proyecto de Constitución. Su debate en el Pleno}

\subsubsection{La discusión sobre el art. 5}

Sabemos por el Diario de Sesiones que la lectura de las «dos primeras partes» del Proyecto de Constitución absorbió por completo a las Cortes durante toda la sesión del 18 de agosto de $1811^{37}$. Sin embargo, no comenzaron a deliberar sobre sus previsiones hasta el 25 del mismo mes ${ }^{38}$ y sólo el día 30 le tocaría el turno al art. 5, evidenciándose inmediatamente que en tan comprimida declaración de derechos como pretendía ser la de su inciso final no hubo lugar para la igualdad.

En efecto, poco después de iniciarse la discusión del citado artículo manifestó Ortiz echar de menos en él una referencia explícita a la igualdad legal y pidió que se le añadiese porque, según dijo, «siendo unos los derechos primitivos del ciudadano, debe haber igualdad legal: esto es un hecho: delante de la ley, todos son iguales ${ }^{39}$.

Recibió esta propuesta de adición dos objeciones. La primera de Calatrava quien dijo no ser el art. $5^{\circ}$ el lugar oportuno para acogerla en base al siguiente argumento: «aquí hablamos de los derechos de todos los que componen la Nación y no todos tienen esa igualdad legal. Una cosa es ser español, otra es gozar de los derechos de ciudadano. Estos serán legalmente iguales, no los primeros; por tanto si ha de ponerse adición póngase en el capítulo en que se trata de los ciudadanos $^{40}$. Tampoco Muñoz Torrero se mostró dispuesto a compartir la propuesta

${ }^{34}$ Cfr. Actas de la Comisión de Constitución, cit. p. 229.

35 D.S.C.G.E., núm. 448, de 24 de diciembre de 1811, p. 2475.

36 D.S.C.G.E., núm. 449, de 26 de diciembre de 1811, p. 2477.

37 D.S.C.G.E., núm. 320, de 18 de agosto de 1811, p. 1651.

${ }^{38}$ Las palabras que pronunció ese día el Presidente de la Cámara no dejan lugar a dudas D.S.C.G.E., núm. 327, de 25 de agosto de 1811, p. 1683.

39 D.S.C.G.E., núm. 332, de 30 de agosto de 1811, p. 1730.

${ }^{40}$ Cfr. Ibíd. 
de Ortiz aunque por razones distintas a las alegadas por Calatrava. Según Muñoz Torrero: «No se ha puesto la igualdad porque ésta, en realidad, no es un derecho, sino un modo de gozar de los derechos. Este modo debe ser igual en todos los individuos que componen la Nación» ${ }^{41}$.

Aún pediría Leiva, aunque infructuosamente, que se votara la adición propuesta por Ortiz y que se explicara la distinción entre españoles y ciudadanos en que se había basado Calatrava para oponerse a la inclusión en el art. 5 de una mención expresa a la igualdad ante la ley. En palabras de Leiva: «sancionándose esta igualdad todo español será uno delante de la ley. En una contienda, por ejemplo, es necesario que sea considerado igualmente el hijo del más humilde español que el de un grande de España de primera clase» ${ }^{42}$.

Ninguno de los diputados que intervinieron en el debate negó lo evidente, es decir, que el art. 5 del Proyecto de Constitución carecía de una mención expresa a la igualdad. En su discusión expusieron diferentes ideas representativas, en última instancia, de dos corrientes contrapuestas de opinión, la de quienes proponían añadirle a la disposición la referencia que omitía y la de quienes con tan buenos argumentos como los de aquellos se resistían a la operación. Empezando por estos últimos no parecía faltarle la razón a Calatrava pues ¿cómo iba a mencionar la igualdad el Proyecto de Constitución en su art. 5 cuando en el art. 6 se mostraba a favor de la esclavitud ${ }^{43}$; si de acuerdo con una interpretación sistemática de sus títulos I y II, el Proyecto diferenciaba entre españoles y ciudadanos; y todavía en este Título II ponía serias trabas a los que por cualquier línea trajeran origen de África para acceder al «status « de ciudadano? ${ }^{44}$ En otras palabras ¿cómo iba a mencionarse expresamente la igualdad si no todos los nacidos en los territorios de las Españas eran considerados españoles y a una significativa parte de éstos se les negaba en principio la calidad de ciudadanos?

${ }^{41}$ Cfr. Ibíd.

${ }^{42}$ Cfr. Ibíd. p. 1731.

43 En efecto, según el art. 6 eran españoles: Primero.- Todos los hombres libres nacidos y avecindados en los dominios de las Españas y los hijos de éstos (...). Quinto.- Los libertos desde que adquieran la libertad en España.

44 A este respecto, disponía el art. 22 del Proyecto: «A los españoles que por cualquier línea traen origen de África, para aspirar a ser ciudadanos les queda abierta la puerta de la virtud y del merecimiento, y en su consecuencia, las Cortes podrán conceder carta de ciudadano a los que hayan hecho servicios eminentes a la Patria, o a los que se distingan por sus talentos, su aplicación y su conducta; bajo condición respecto de estos últimos, de que sean hijos de legítimo matrimonio, de padres ingenuos, de que estén ellos mismos casados con mujer ingenua, y avecindados en los dominios de España, de que ejerzan alguna profesión, oficio o industria útil con un capital propio, suficiente a mantener su casa y educar a sus hijos con honradez». 
No se oponía Calatrava a que se declarase la igualdad en la futura Constitución, sólo discrepaba de que fuese oportuno hacerlo en donde lo pretendía Ortiz, pues en ese caso los españoles se hubiesen visto indefectiblemente beneficiados por una proclamación que, según Calatrava, debía efectuarse en provecho del más reducido círculo de los ciudadanos. Con toda lógica, por cierto, dadas las diferentes categorías de estatutos personales que perseguía implantar el Proyecto de Constitución atendiendo al nulo, relativo o completo reconocimiento de los derechos civiles y políticos que enunciaba para, a la postre, reservar el disfrute de una y otra clase de derechos, en su integridad, a los ciudadanos.

Tampoco Muñoz Torrero carecía de razón al negar que la igualdad fuese un derecho, pues de serlo ¿cómo conciliarlo con la distinción entre españoles y ciudadanos en que se basaba el Proyecto? ¿Cómo hubiera podido la futura Constitución negar a los españoles la condición de ciudadanos sin incurrir en una enorme contradicción con uno de los postulados esenciales en que se pretendía sustentarla? Si se consideraba que la igualdad era un derecho hubiera debido prescindirse de la diferencia que se perseguía establecer en el Proyecto entre españoles y ciudadanos, a menos que se definiese a la igualdad concediéndole un alcance no incompatible con dicha distinción al estilo de las declaraciones francesas de 1789 y 1795.

Por lo que se desprende de la discusión habida en el Pleno no es difícil imaginar qué clase de dudas debieron asaltar a la Comisión ante el dilema de mencionar expresamente a la igualdad en el Proyecto, y de proponer al mismo tiempo en él un modelo de sociedad asentada en colectivos jurídicamente caracterizados por la diversa naturaleza de los derechos que se les pretendía reconocer a sus miembros, cuando no se les negaba completamente. Prescindiendo de cualquier referencia a la igualdad no se mostraba de manera tan evidente la paradoja que, sin embargo, subsistía, como hizo recordar a las Cortes la propuesta, en absoluto ajena a los postulados de la Comisión, que formulara Ortiz, respaldándola con un argumento que se nos antoja manifestación de una idea más amplia en la que la igualdad era considerada una categoría de los derechos civiles y éstos, a su vez, necesariamente generados por el pacto «societatis«: «porque siendo unos los derechos primitivos del ciudadano debe haber igualdad legal».

Es indiscutible que la propuesta de Ortiz respetaba el parecer reiteradamente manifestado por la Comisión respecto a la igualdad. No en balde, según consta en el acta de la sesión de 29 de marzo, se dijo que se trataba de un derecho, recibió esa consideración en cuantas ocasiones se refieren a ella las actas y cuando por fin decidió la Comisión no aludir expresamente a la igualdad en el Proyecto no dejó por eso de considerarla un derecho, como lo revelan los términos del acuerdo adoptado al efecto el 7 de agosto: «que a continuación del art. $5^{\circ}$ 
(...) se indicasen o expresasen las definiciones de los tres primeros derechos y oblicuamente se insinuase el cuarto», es decir, la igualdad. Ortiz, en definitiva, no hizo sino recordar que entre el modelo de sociedad que proponía la Comisión y la naturaleza que ésta asignaba a la igualdad, se daba una contradicción. Salvarla requería algo más que evitar mencionar expresamente a la igualdad, demandaba decidirse por uno de sus términos encontrados y prescindir del otro. Se imponía, pues, abandonar la distinción entre españoles y ciudadanos que se perseguía establecer o renunciar a la igualdad como derecho, a menos que se aclarase, insistimos, a qué categoría pertenecía —o cual era su radio de acción-, definiéndola en suma, como pensó hacer la Comisión cuando especuló con la idea de incluir un listado de derechos en el Proyecto de Constitución del que luego prescindió. Aunque sólo se hubiese dicho lo que entonces, esto es, que entre los españoles no habría diferencias en lo referente al ejercicio de los derechos civiles. Para decidirse por esta última solución se contaba con el inestimable apoyo teórico que proporcionaba el diferente tratamiento que recibió la igualdad en las sucesivas declaraciones de derechos francesas del siglo XVIII, conocido casi con toda seguridad en las Cortes. Sería Muñoz Torrero quien, sin servirse empero de dicho argumento, acometería esa empresa. De acuerdo con Calatrava identificó a la igualdad con un modo de gozar de los derechos civiles que contemplaba el Proyecto de Constitución, sin discutir por ello que los españoles, sin excepción, estuvieran llamados a disfrutar de tales derechos, antes bien, manifestando que así habría de ser.

A la postre, esa sería como veremos, la solución que propondría el Proyecto de Código Civil de 1821. En cuanto a la Constitución, no aceptaron las Cortes la enmienda de Ortiz sin que sea posible determinar si participaban o no de los argumentos que los citados diputados alegaron para rechazarla y privar a la Constitución de una referencia a la igualdad; pues si bien aprobó la Cámara el art. 5 del Proyecto en los mismos términos que propuso la Comisión, lo hizo sin manifestarse en ningún momento sobre si la igualdad era o dejaba de ser un derecho, a causa, sin duda, de que el laconismo de la disposición no propiciaba pronunciamientos al respecto. Con ello darían las Cortes el primer paso del camino que recorrerían hasta arribar a la distinción entre españoles y ciudadanos que, conforme a las previsiones del Proyecto de Constitución, también concluirían consagrando, a base de reconocer a los primeros la titularidad de los derechos civiles y a los segundos los de esa clase unidos a los de carácter político. Tales fueron, como tendremos ocasión de ver, las dos categorías de derechos que incorporaron a la Constitución las Cortes constituyentes luego de invocárseles reiteradamente en su seno por esos nombres y de concedérseles, como correspondía, diferentes significados y alcances. Siendo incuestionable que en este 
planteamiento influyeron algunas construcciones constitucionales francesas, también podría haberlo inspirado y, hasta directamente, los postulados de otra fuente normativa francesa, su Código Civil de 1803. Vinculadas a la posible influencia de sus previsiones en el ánimo de los diputados gaditanos atisbamos además razones para que las Cortes ni siquiera incluyeran en la Constitución una referencia a la igualdad legal o a la igualdad ante la ley que era, en el fondo, el meollo de la solicitud suscrita por Ortiz y secundada por Leiva. Luego insistiremos sobre ambos asuntos, antes debemos ocuparnos de la distinción entre ciudadanos y españoles, así como de los derechos que a unos y otros asignaba el Proyecto de Constitución.

\subsubsection{La polémica sobre las castas}

A este respecto se hace ineludible acudir a las deliberaciones que se verificaron en las Cortes entre el 4 y el 7 de septiembre, motivadas precisamente por la separación que, entre ambas categorías jurídicas, pretendía establecer el Proyecto de Constitución y que finalmente aceptaron las Cortes incluir en la Ley Fundamental luego de discutirlo, como decimos, largamente. En efecto, a causa de la fuerte oposición que mostraron los diputados americanos a la propuesta de la Comisión, por considerarla injusta para las castas, se produjo un dilatado debate en el curso del cual se formularon declaraciones sobre la referida distinción entre españoles y ciudadanos que no conviene ignorar. Una de las más interesantes, por el significado que concedía a la separación entre ambas clases de colectivos la realizó, el 6 de septiembre, Muñoz Torrero erigiéndose en portavoz de la Comisión:

«Expondré brevemente las ideas de la Comisión en esta materia tan delicada, para que se entienda cual es el motivo que obligó a hacer esta distinción entre españoles o ciudadanos. Hay dos clases de derechos unos civiles y otros políticos: los primeros generales y comunes a todos los individuos que componen la Nación, son el objeto de la justicia privada, y de la protección de las leyes civiles; y los segundos pertenecen exclusivamente al ejercicio de los poderes públicos que constituyen la soberanía. La Comisión llama españoles a los que gozan de los derechos civiles, y ciudadanos a los que al mismo tiempo disfrutan de los políticos ${ }^{45}$.

No menos interesante fue la declaración que al día siguiente efectuó Espiga, más complementaria que reiterativa de la que había realizado Muñoz Torrero en

45 D.S.C.G.E., núm. 339, de 6 de septiembre de 1811, p. 1790. 
la jornada anterior. El 7 de septiembre, en efecto, participaría Espiga en el debate que sobre las castas venía desarrollándose en el Pleno desde el día 4. De su dilatada intervención, atenta a muy variadas cuestiones, destacaremos, primero, que pretendía justificar la distinción propuesta por la Comisión entre españoles y ciudadanos con argumentos tanto de carácter histórico tradicional como de tipo racionalizador; pues sostenía Espiga que siempre y en todo lugar habían existido esclavos, libertos, hombres libres y ciudadanos, y que decidida la Nación a darse una Constitución era soberana para establecer un orden social basado en tantas categorías o colectivos de personas como juzgase oportuno. Por otro lado, entendía obvia la indisoluble relación que, de acuerdo con la propuesta de la Comisión, vinculaba a la distinción entre españoles y ciudadanos, de un lado, con la titularidad de los derechos civiles y políticos, de otro. De llamar la atención sobre el trascendental papel que, en aquella distinción, habrían de jugar ambas categorías de derechos se ocuparía también Espiga en su discurso, parcialmente referido además a delimitar sus respectivos significados y alcances.

«(...) en todos los gobiernos antiguos y modernos (...) la ley ha distinguido los esclavos, los libertos, los hombres libres y los ciudadanos y marcado estos intervalos políticos con derechos y obligaciones diferentes (...). La Nación, señor, se puede considerar de dos maneras: o en su parte política que es su Constitución, o en su parte legal, que es su legislación. En la primera, la Nación tiene el indudable y soberano derecho de poner todas aquellas condiciones que crea conveniente para su más sabia constitución; y por consiguiente, el de fijar las cualidades que hayan de tener los que han de ser llamados al ejercicio de ella (...). Por una consecuencia de estas relaciones políticas, el individuo de una Nación puede considerarse con respecto a la potestad legislativa y en este supuesto todos deben ser iguales en derechos y nadie debe ser excluido de ninguno; pero si se considera con relación a la parte constitutiva, no tiene un derecho necesario, y solo le tendrá cuando esté adornado de las cualidades que requiere la ley fundamental, para obtener los empleos constitucionales. No será diputado de las Cortes pero las leyes que pronuncie este augusto Congreso, protegerán igualmente al español que al ciudadano. No será juez, ni magistrado; pero la justicia se administrará con igualdad. No será oficial del ejército; pero la fuerza armada le defenderá de toda violencia como a los demás» ${ }^{46}$.

Como se advierte enseguida, los discursos que el 6 y el 7 de septiembre pronunciaron respectivamente Muñoz Torrero y Espiga respondían a una misma línea de pensamiento que, casi con toda seguridad, alumbró las deliberaciones de la Comisión en la que ambos se integraban y que muy probablemente compar-

46 D.S.C.G.E., núm. 340, de 7 de septiembre de 1811, pp. 1795 a 1799. 
tían sus demás miembros. No en balde, la declaración de Espiga completaba la de Muñoz Torrero del 6 de septiembre, conectaba con lo que este último había dicho el 30 de agosto a propósito de la igualdad, e incluso sintonizaría con el tratamiento que, como veremos, le dispensó algo después el Discurso Preliminar. Pero por más que ambos discursos se significasen por prestar una particular atención a la igualdad ante la ley, no puede decirse que fuera ésta una nota o cualidad exclusiva de los mismos, pues también caracterizaba a las intervenciones de otros diputados participantes en el debate sobre las castas, que, por esta causa, admite ser considerado continuación del que se produjo el 30 de agosto en torno al art. 5 .

No fueron, en efecto, Espiga y Muñoz Torrero los únicos que entre el 4 y el 7 de septiembre se pronunciaron sobre la igualdad ante la ley, ni puede decirse tampoco que sus afirmaciones al respecto fuesen las más sobresalientes desde el punto de vista conceptual. A lo largo de esos días se produjeron otras intervenciones mucho más interesantes desde esa perspectiva y que ilustran respecto al alto grado de conocimiento que se tenía en las Cortes de las construcciones teóricas y constitucionales francesas sobre la igualdad. Un clima como ese propiciaba sin duda que el autor del Discurso Preliminar terminara pronunciándose respecto a la igualdad ante la ley en términos tan certeros como luego veremos, si no es que se inspiró directamente en alguna de las intervenciones de que hablamos. Una de las más destacadas fue la de Pérez de Castro del 5 de septiembre. En ella demostró ser plenamente consciente de estar contribuyendo a levantar un edificio en el que la Constitución con ser su parte más importante no era la única, pues, por lo que se desprende de sus palabras, parecía esperar que unos futuros códigos innominados y subordinados a la Constitución completarían sus previsiones relativas a los derechos civiles. De estos últimos habló en su intervención orientada a subrayar que las castas, en cuanto españoles, serían sus beneficiarios. Con ese objetivo, en efecto, enumeró tales derechos antes de referirse, sin solución de continuidad, a la igualdad ante la ley, para manifestar respecto a la misma lo que quizá hubiera podido deducirse sencillamente atendiendo al contexto de su declaración, es decir, que la consideraba un derecho:

«Porque cuando nuestros códigos se repasen y rectifiquen con arreglo a la Acta constitucional, ¿qué podrá decir el puramente español, el originario de África, al ver sólidamente canonizado el derecho de propiedad, el más sagrado entre los hombres, auténticamente establecida la libertad civil, la seguridad personal, y el derecho a ser juzgado con igualdad por una misma ley?» ${ }^{47}$.

47 D.S.C.G.E., núm. 338, de 5 de septiembre de 1811, p. 1780.

(C) UNED. Revista de Derecho Político

N. ${ }^{\circ} 82$, septiembre-diciembre 2011, págs. 193-238 
Protagonizaría la segunda de las intervenciones que juzgamos conveniente subrayar Leiva, quien, pese a formar parte de la Comisión disentía del parecer mayoritario entre sus miembros de negar a los libertos o castas los derechos políticos, como lo demuestran las palabras que el referido diputado pronunció el 6 de septiembre:

«(...) es muy distinta la igualdad jacobiana de la igualdad racional y legal. Aquella, confundiendo todas las clases y gerarquías de la sociedad produce la anarquía y todos los horrores que le son consiguientes. Viola la justa y equitativa ley de los premios, del mérito y la virtud

Los grandes hombres por servicios eminentes consiguieron la nobleza agnaticia y la patria agradecida transmitió sus honores a sus hijos para que les imitasen. Otros adquirieron y dejaron a su posteridad otra nobleza de segundo orden. En todos los ramos del servicio público debe haber grados con escala sucesiva para que se verifique la referida ley de los premios. Estas instituciones eran odiosas a aquellos hombres depravados, que ocultando la ambiciosa idea de subir respectivamente a la cumbre del poder, aparentaban defender una igualdad quimérica. Esta idea martirizó una gran parte de la nación francesa y produjo su espantosa convulsión. Pero la igualdad racional consiste en abrir a los españoles la carrera de los premios en términos que con buenas esperanzas puedan practicarse las virtudes que son tan necesarias para la felicidad de la sociedad. Que el ciudadano no es otra cosa que un estado de hombres buenos, que se hallan en aptitud de poder ser premiados y atendidos según sus méritos» ${ }^{48}$.

Si Leiva atribuía diferentes significados a la igualdad, más o menos fundados en elaboraciones teóricas procedentes de Francia e incluso relataba a su modo lo que allí había sucedido a causa de lo que juzgaba un incorrecto entendimiento de la igualdad, Larrazábal demostraría estar al corriente del tratamiento que había recibido ésta en dicho país. No en balde, casi reprodujo en su intervención del 6 de septiembre los enunciados de los artículos 3 y 4 de la Declaración de derechos francesa de 1793. En otro orden de cosas debe resaltarse además que coincidía con Pérez de Castro en calificar a la igualdad ante la ley como un derecho:

«La sociedad humana es la unión de hombres ligados entre sí con un vínculo indisoluble, y su objeto es el mejor estar de los individuos que la componen: se estableció su gobierno para su conservación y tranquilidad; ésta atiende al goce de sus derechos naturales e imprescriptibles. Estos derechos son, entre otros, la igualdad que consiste en que la ley debe ser la misma para todos, ya proteja, ya

48 D.S.C.G.E., núm. 339, de 6 de septiembre de 1811, p. 1786. 
castigue: que no pueda ordenar sino lo que es justo y útil a la sociedad, ni prohibir sino lo que le es perjudicial» ${ }^{49}$.

\subsection{La segunda entrega del Discurso Preliminar y del Proyecto de Constitución}

El 5 de noviembre supieron las Cortes por Argüelles que la Comisión había concluido «la tercera parte» del Proyecto de Constitución ${ }^{50}$. Como las dos primeras, estaba prologada por un fragmento de Discurso Preliminar que se leyó, con el del Proyecto, al día siguiente en la Cámara ${ }^{51}$. La redacción de esta segunda entrega se produjo entre el 23 de agosto y el 5 de noviembre, esto es, en un periodo de tiempo durante el cual discutieron las Cortes, en primer lugar, sobre el art. 5 del Proyecto, y respecto de las castas un poco después. En consecuencia, la Comisión tuvo la oportunidad de tomar buena nota de ambos debates y muy probablemente pesaron en el ánimo de sus miembros a la hora de redactar las partes del Discurso Preliminar y del Proyecto de Constitución que nos ocupan. Sea como fuere, sus respectivos contenidos sintonizaban estrechamente con ciertas opiniones manifestadas en el curso de una u otra deliberación. No es ocioso recordar al respecto que en la sesión del 30 de agosto rechazó el Pleno la enmienda suscrita por Ortiz al art. 5 del Proyecto, aprobándolo en los mismos términos que había propuesto la Comisión y privándolo así de una referencia expresa a la igualdad ante la ley que, por otro lado, no contemplaba ninguna otra de sus disposiciones, ni tampoco llegó a proclamar la Constitución. Puede que dicha enmienda y las protestas de Leiva de aquél día no cayeran, sin embargo, en saco roto e influyeran para que la Comisión resolviese mencionar a la igualdad ante la ley en la segunda entrega del Discurso Preliminar, en donde, en cualquier caso, se hablaba de ella y en varias ocasiones por cierto.

\subsubsection{La igualdad ante la ley en el Discurso Preliminar}

En la primera referencia a la igualdad ante la ley que albergaba esta parte del Discurso Preliminar parecía quererse destacar su importancia:

«Así es que en un estado libre puede haber personas que por circunstancias particulares no concurran mediata o inmediatamente a la formación de las leyes positivas; mas éstas no pueden conocer diferencia ninguna de condición ni de cla-

49 D.S.C.G.E., núm. 339, de 6 de septiembre de 1811, p. 1787.

50 D.S.C.G.E., núm. 399, de 5 de noviembre de 1811, p. 2217.

51 D.S.C.G.E., núm. 400, de 6 de noviembre de 1811, p. 2219. 
ses entre los individuos de este mismo estado. La ley ha de ser una para todos, y en su aplicación no ha de haber acepción de personas.

De todas las instituciones humanas ninguna es más sublime ni más digna de admiración que la que limita en los hombres la libertad natural, sujetándoles al suave yugo de la ley. A su vista todos aparecen iguales y la imparcialidad con que se observen las reglas que prescriben, será siempre el verdadero criterio para conocer si hay o no libertad civil en un estado (...)» ${ }^{52}$.

No son tan numerosas las afirmaciones que incluye el breve pasaje transcrito y eso facilita desde luego la sistematización de ideas que nos sugiere su lectura. Inmediatamente nos ocuparemos de ello, persuadidos de que no conviene pasar por alto ninguno de sus contenidos. Son dos las cuestiones que interesa destacar al respecto. En primer lugar, la distinción que en él se hacía entre admitidos y excluidos a participar en la formación de la ley, en absoluto sorprendente teniendo en cuenta que a estas alturas del 6 de noviembre ya habían resuelto las Cortes diferenciar entre españoles y ciudadanos, llamados o no a disfrutar de los derechos políticos. Tales diferencias, sin embargo, no contaban para la ley, así se decía también en dicho pasaje del que no puede ignorarse, en segundo lugar, la claridad conceptual con que era enunciado, como anunciábamos, el principio de igualdad ante la ley. Adviértase que se le dotaba de un doble significado de acuerdo con el cual la ley debía ser la misma para todos y a todos había de aplicarse de idéntica forma: «la ley ha de ser una para todos y en su aplicación no ha de haber acepción de personas».

Tan afortunada conceptuación de la igualdad ante la ley no era la única consideración que al respecto hacía el Discurso Preliminar. Más adelante volvería a ocuparse de la misma para afirmar con cierta insistencia que había sido proclamada en la primera parte de la Constitución, aprobada ya, desde luego, al tiempo de leerse la segunda entrega del Discurso Preliminar en las Cortes. No menor importancia tenían las consecuencias que la Comisión anudaba a la proclamación de la igualdad ante la ley, descritas en otros dos pasajes del Discurso Preliminar que reproducimos juntos prescindiendo de las largas reflexiones que los separaban:

«La igualdad de derechos proclamada en la primera parte de la Constitución en favor de todos los naturales de la monarquía, la uniformidad de principios adoptada por V.M. en toda la extensión del vasto sistema que se ha propuesto, exigen que el código universal de leyes positivas sea uno mismo para toda la Nación» ${ }^{53}$ «(..) La

${ }_{52}$ Cfr. Sevilla Andrés Constituciones y otras leyes y proyectos políticos de España, vol. I, cit. p. 136.

53 Cfr. Ibíd. p. 140. 
nueva ley fundamental que se establece sentando por principio la igualdad de los españoles, la imparcial protección que a todos dispensa la Constitución y los medios que sanciona para alcanzar la observancia de las leyes hace inútil e inoportuno el privilegio de caso de corte» ${ }^{54}$.

¿Por qué cuando ningún artículo del Proyecto mencionaba expresamente la igualdad ante la ley se afirmaba en los pasajes transcritos que había sido proclamada en la primera parte de la Constitución o que ésta se asentaba sobre el principio de igualdad legal de todos los españoles?

Por lo que sabemos, cuando la Comisión redactó esta parte del Discurso Preliminar el Pleno había aprobado ya el art. 5 del Proyecto. Por consiguiente, es sumamente improbable que ignorase el evento, así como las circunstancias en que se produjo, y si a pesar de todo insistía en afirmar haberse proclamado la igualdad ante la ley era por alguna razón que se nos antoja fundamentada en una interpretación gramatical de la citada disposición, que avalaría además la crónica de su aprobación.

Recuérdese que tanto Calatrava como Muñoz Torrero se opusieron a incluir en el artículo una referencia a la igualdad ante la ley por considerarla un modo de gozar de los derechos y que en opinión de Muñoz Torrero, además, no era un derecho. Desde luego que las Cortes lo aprobaron en los mismos términos propuestos por la Comisión, pero no se olvide tampoco que, en realidad, no llegaron a manifestarse sobre si la igualdad ante la ley era o dejaba de ser un derecho. Su enunciado no lo permitía. De suerte que es imposible saber si compartían o no las opiniones de ambos diputados y, en particular, la de Muñoz Torrero. Atendiendo a esta circunstancia es muy probable que, al tiempo de redactar esta segunda parte del Discurso Preliminar, la Comisión, fiel a su pronunciamiento del 29 de marzo, estimase que la igualdad era un derecho y entendiese que debía considerarse implícitamente proclamada en el inciso final del artículo: «y los demás derechos legítimos de todos los individuos que la componen». Favorecía o facilitaba ese modo de concebir la igualdad ante la ley el clima de acuerdo reinante en la Cámara respecto a su significado y alcance, tan propicio como para no precisarse a estas alturas del debate de las precauciones frente a malentendidos que probablemente tomaba Muñoz Torrero cuando le negaba esa naturaleza; tan intenso como para que en él germinase la aquilatada definición de la igualdad ante la ley que, según hemos visto, ofrecía el Discurso Preliminar.

\footnotetext{
${ }^{54}$ Cfr. Ibíd. p. 142.
} 


\subsubsection{Unidad de jurisdicción y voluntad codificadora en el Proyecto de Constitución}

Además, no deben pasar inadvertidos otros asuntos tratados en los pasajes transcritos del Discurso Preliminar que hablaban de haberse proclamado la igualdad ante la ley en la primera parte de la Constitución. Nos referimos a las afirmaciones que allí se hacían a propósito de un «código universal de leyes positivas» único para «toda la Nación» y de la abolición del «privilegio de caso de corte». Las primeras de las manifestaciones a que aludimos revelan, de un lado, que la Comisión sintonizaba con uno de sus miembros, Pérez de Castro, y asumía la idea de la relación de complementariedad entre la Constitución y los futuros códigos que el 5 de septiembre enunciara dicho diputado. De otro, que la Comisión quiso profundizar aún más en ella e indicar qué tipo de lazo vinculaba a los términos de dicha relación, pues no en balde decía que un código de las señaladas características era exigido por la proclamación constitucional de la igualdad ante la ley o, por usar sus propias palabras, de la igualdad de derechos. La abolición del privilegio de caso de corte, por último, era inherente a la unidad jurisdiccional que proponía implantar la Comisión como consecuencia de esa supuestamente proclamada igualdad ante la ley, en todo caso defendida como principio articulador del nuevo orden jurídico-político en construcción por quienes integraban aquél órgano.

Mucho decía esta segunda parte del Discurso Preliminar sobre la unidad jurisdiccional. Nos desbordaría ocuparnos de tales asertos como se merecen y nos limitaremos, por tanto, a reproducir algunos de los más intensamente relacionados con la cuestión de que venimos tratando:

«La Comisión no necesita detenerse a demostrar que una de las principales causas de la mala administración de justicia entre nosotros es el fatal abuso de los fueros privilegiados introducidos para ruina de la libertad civil y oprobio de nuestra antigua y sabia constitución (...) ¿Qué subterfugios, qué dilaciones, qué ingeniosas arbitrariedades no presentan los fueros particulares a los litigantes temerarios, a los jueces lentos o poco delicados, a los ministros de justicia que quieran poner a logro el caudal inmenso de su cavilosa sagacidad! La sola nomenclatura y discernimiento de los fueros privilegiados exigen un estudio particular y meditado. La justicia, señor, ha de ser efectiva, y para ello su curso ha de estar expedito. Por lo mismo, la Comisión reduce a uno sólo el fuero o jurisdicción ordinaria en los negocios comunes, civiles y criminales (...) $»^{55}$.

55 Cfr. Ibíd. p. 139. 
Consecuentemente con lo que afirmaba en la segunda parte del Discurso Preliminar propuso la Comisión en la correspondiente del Proyecto establecer una sola jurisdicción y proceder a la codificación anunciada. En el art. 147 del Proyecto consignó la primera de dichas proposiciones de la manera que expresa su dicción literal:

«En los negocios comunes civiles y criminales no habrá más que un sólo fuero para toda clase de personas».

Los términos concretos de la segunda propuesta fueron cuidadosamente meditados por la Comisión ${ }^{56}$ antes de llegar a formularlos en el art. 257 de su proyecto del siguiente modo:

«El Código civil, el criminal y el de comercio serán unos mismos para toda la Monarquía, sin perjuicio de las variaciones que por particulares circunstancias podrán hacer las Cortes».

En la sesión del 21 de noviembre resolvería el Pleno aprobarlo en los mismos términos propuestos por la Comisión, tras una tímida discusión a propósito de su inciso final no del todo bien vista por algunos diputados americanos recelosos de que pudiera tener alguna consecuencia discriminatoria para sus coterráneos. Fue Gordoa quien abogó resueltamente por que se eliminase dicho inciso alegando entre otras cosas lo siguiente:

«Estas y otras reflexiones que no pueden ocultarse a V.M., me persuaden de la necesidad de que hay que suprimir la segunda parte del artículo, o de que se aclare más su sentido, para que entiendan todos los ciudadanos españoles que el Código universal de leyes positivas será uno mismo para toda la Nación, como sabiamente se expresa en el discurso preliminar; lo exige la igualdad de derechos proclamada en la primera parte de la Constitución» ${ }^{57}$.

Así, pues, incluso Gordoa estaba convencido de que la igualdad ante la ley había sido proclamada en la primera parte de la Constitución y consideraba que la adopción de un código universal de leyes positivas era una exigencia necesaria de aquella igualdad de derechos.

56 Suficientemente expresiva al respecto es el acta correspondiente a la sesión del 29 de agosto: «Se presentó a la deliberación el artículo que trata de que sea uno mismo el Código Civil, el Criminal y el de Comercio para toda la Monarquía. Hicieronse algunas reflexiones con respecto a las provincias de Ultramar y no quedando nada decidido en la discusión se reservó para la sesión siguiente». En ella, celebrada el 30 de agosto, resultaría por fin aprobado, Cfr. Actas de la Comisión de Constitución, cit. pp. 176 y 177.

57 D.S.C.G.E., núm. 415, de 21 de noviembre de 1811, pp. 2306. 


\section{LA SOLUCIÓN CONSTITUCIONALMENTE ADOPTADA}

\subsection{Esclavos, libertos, hombres libres y ciudadanos}

Considerando cuanto se ha venido diciendo hasta aquí no es difícil adivinar qué tratamiento concedieron las Cortes constituyentes a la igualdad. En todo caso juzgamos oportuno reseñarlo comenzando por describir el contexto de previsiones constitucionales en que se integraba. A tal efecto, ha de señalarse que, según estipulaba el art. 5 de la Constitución en su párrafo primero, eran españoles «todos los hombres libres nacidos y avecindados en los dominios de las Españas», los extranjeros que hubiesen obtenido carta de naturaleza o contaran con diez años de vecindad en «cualquier pueblo de la Monarquía» y los libertos desde que adquiriesen la libertad en «las Españas». Tan incuestionable pronunciamiento favorable a la esclavitud no requiere de ningún comentario adicional a propósito de su significado, pero sí debe subrayarse al respecto que la Constitución no sólo perpetuaba tal estado, sino que ponía serias trabas a los «originarios de África» para adquirir la ciudadanía. No en balde, en virtud de lo dispuesto en el art. 22, los españoles que por cualquier línea fuesen «originarios de África» podrían obtener carta de cudadano de las Cortes cuando «hicieren servicios cualificados a la patria, se distinguiesen por su talento, aplicación o conducta» y siempre que fuesen hijos legítimos de ingenuos, hubiesen contraído matrimonio con ingenua, estuviesen avecindados en los dominios de las Españas y ejerciesen alguna profesión, oficio o industria útil con capital propio. En resumidas cuentas, no puede decirse que la igualdad natural fuese motivo de preocupación para los constituyentes de 1812.

Además, la distinción entre españoles y ciudadanos era en sí misma trascendental, toda vez que sólo los ciudadanos eran titulares de los derechos políticos. No bastaba con ser español para acceder a los empleos públicos, el art. 23 era terminante en este sentido:

«Sólo los que sean ciudadanos podrán obtener empleos municipales y elegir para ellos en los casos señalados por la ley».

Tampoco estaban llamados los españoles a participar en la elección de los representantes de la Nación, el derecho de sufragio estaba constitucionalmente reservado a los ciudadanos que, además, no se encontrasen en ninguna de las situaciones previstas en el art. 25 como causas suspensivas de su ejercicio. No mencionaremos todas, únicamente la domesticidad citada en su párrafo tercero — explícitamente condenada por la Declaración de derechos francesa de 1793, 
aunque no por la de 1795 - y la descrita en el párrafo sexto del referido artículo en términos que recuerdan a los del art. 6 de la Declaración de 1795:

«Desde el año de mil ochocientos treinta deberán saber leer y escribir los que de nuevo entren en el ejercicio de los derechos de ciudadano».

De acuerdo con el sistema electoral previsto en la Constitución, únicamente los ciudadanos en el ejercicio de sus derechos, vecinos y residentes de una parroquia podrían designar entre sí a quienes considerasen conveniente, siempre que además de los señalados requisitos contasen con 25 años de edad. Los designados como electores parroquiales nombrarían a los electores de partido que, a su vez, elegirían a los diputados provinciales entre quienes reuniesen los requisitos que al efecto exigía la Constitución, algo distintos de los que demandaba a los aspirantes a cualquier otra categoría de electores citada. Como en los demás casos, los candidatos a diputados habrían de ser ciudadanos en el ejercicio de sus derechos y mayores de 25 años. El art. 91 en esto no faltaba a la regla general que, sin embargo, ignoraba al requerirles además haber nacido en la provincia o estar «avecindado en ella con residencia a lo menos de siete años», cualquiera que fuese su estado, seglar o eclesiástico, y con independencia de que fuesen o no miembros de la «junta electoral de provincia», pues también permitía el citado artículo que la elección recayese en cualquier extraño a la misma. Con ser importantes, las referidas quiebras a la regla general no superaban en calado a las que albergaba el enunciado del art. 92, según el cual únicamente podrían ser diputados quienes tuviesen «una renta anual proporcionada de bienes de propios». No especificaba la disposición a cuanto debía ascender el montante de la renta, de acuerdo con el plan perfectamente trazado por las Cortes y descrito en su segunda parte:

«Suspéndese la disposición del artículo precedente hasta que las Cortes que en adelante han de celebrarse, declaren haber llegado ya el tiempo de que pueda tener efecto, señalando la cuota de la renta y la calidad de los bienes de que hayan de provenir; y lo que entonces resolviesen, se tendrá por constitucional, como si aquí se hallara expresado».

Al referido sistema electoral, aprobado por la Cámara casi en idénticos términos a los propuestos por la Comisión, se refirió esta última en su Discurso Preliminar para sostener, en primer término, haberse inspirado en el modelo de convocatoria a Cortes adoptado por la Junta Central en 1810 y afirmar, en segundo lugar, que había introducido en él algunas variantes. No olvidó mencionar la Comisión cuales eran, ni al describirlas de explicar a qué razón obedecían, fundamental para comprender a su vez qué significado concedía a algunas de las medidas más arriba mencionadas conformadoras de dicho sistema electoral: 
«También se han hecho algunas otras variaciones en el método general de elección en las provincias para evitar los inconvenientes que la experiencia ha manifestado resultar del reglamento de la Junta Central. Las dos innovaciones más principales que se han hecho son las de no requerir precisamente para ser nombrado diputado por una provincia la naturaleza material, por no privar a la Nación de que sean elegidos muchos dignos españoles que por haber salido de sus provincias desde niños, o hecho ausencia de muchos años, pueden ser poco o nada conocidos en ellas. La otra es exigir para diputado la condición de tener una renta anual proporcionada, procedente de bienes de propios.

Nada arraiga más al ciudadano y estrecha tanto los vínculos que le unen a su patria como la propiedad territorial o la industria afecta a la primera. Sin embargo, la Comisión al ver los obstáculos que impiden en el día la libre circulación de las propiedades territoriales, ha creído indispensable suspender el efecto de este artículo hasta que removidos los estorbos, y sueltas todas las trabas que la encadenan puedan las Cortes sucesivas señalar con fruto la época de su observancia» ${ }^{58}$.

A propósito del sistema electoral constitucionalmente adoptado conviene realizar algunas precisiones. No debe extraerse del mismo, en primer lugar, la conclusión equivocada de que ciudadanos y diputados estuviesen ligados por una suerte de vínculo especial. Lo impedía la observancia del principio de representación, en virtud del cual es posible afirmar que los diputados no sólo representaban a la totalidad del cuerpo electoral, sino también a quienes ni siquiera tenían la oportunidad de intervenir en su elección, como parece deducirse de una interpretación sistemática de las disposiciones constitucionales que, a continuación, mencionaremos comenzando por las alusivas a dicho principio. En este sentido establecía el art. 27 que las Cortes eran «la reunión de todos los diputados que representan la Nación, nombrados por los ciudadanos», mientras que el art. 100 calificaba por su parte a los diputados de «representantes de la Nación española». Decir que los diputados nombrados por los ciudadanos representaban a la Nación, significaba tanto como conceder la representación de cuantos colectivos se integraban en el concepto de Nación que ofrecía el art. $1^{\circ}$ de la Constitución, esto es, de los españoles de ambos hemisferios, incluidos los «originarios de África» que no hubieran obtenido carta de ciudadanía de las Cortes, y los ciudadanos suspendidos del ejercicio de sus derechos por algunas de las causas que enumeraba el art. 25. Pero además, en segundo lugar, el referido sistema electoral permitía a los ciudadanos participar personalmente o por medio de sus representantes en la formación de la ley que, por cuanto se ha dicho, no hay

58 Cfr. Sevilla Andrés: Constituciones y otras leyes y proyectos políticos de España, vol. I, cit. p. 128. 
inconveniente en considerarla expresión de la voluntad general, como a cualquier otro acuerdo adoptado por las Cortes.

\subsection{La igualdad ante la ley}

\subsubsection{Acerca de la ley y de su conceptuación constitucional}

La referida circunstancia representaba un rasgo distintivo de la ley que, como se sigue de la interpretación recién efectuada de la Constitución, ésta, sin lugar a dudas, consagraba, aunque naturalmente no fuera el único. Sin ánimo de exhaustividad y a los solos efectos de ofrecer una visión más completa de la cuestión, deben mencionarse algunas otras características también consignadas en el texto constitucional. Y en este sentido, quizá no sea ocioso señalar que su fuente de inspiración inmediata eran las constituciones francesas de 1791, 1793 y 1795, especialmente la primera, donde la ley en su conjunto recibió, sin embargo, un tratamiento mucho más minucioso del que obtuvo en la Constitución de 1812. Por eso, no es de extrañar que, aun adoptando la Constitución de Cádiz los postulados que respecto a la ley sentaron aquellas, incluidos los relativos a sus cualidades distintivas, los enunciara en su mayor parte de manera implícita.

La Constitución de 1812 asumió en su Título II el principio de separación de poderes que anteriormente habían proclamado las Cortes generales y extraordinarias mediante el Decreto de 24 de septiembre de 1810. Destinaba la Constitución a formular el principio los artículos 15 a 17, en donde, con arreglo a la técnica empleada en 1810, les encomendaba a los órganos estatales allí enumerados el ejercicio de las potestades legislativa, ejecutiva y judicial. Pues bien, interesa subrayar que el primero de los citados artículos disponía textualmente lo siguiente: «La potestad de hacer las leyes reside en las Cortes con el Rey». El dictado en cuestión no nos parece relevante porque inaugurase la lista de referencias constitucionales a la ley, en todo caso poco numerosas. Si acentuamos su importancia es porque aludía a un concepto de ley reservado para las normas adoptadas por un órgano concreto, de una determinada forma, como señaló atinadamente al respecto Ignacio de Otto, por quien sabemos también que de ese órgano estaba llamado a ser su titular la autoridad suprema en el Estado conforme a la tradición filosófica occidental. «En el pensamiento jurídico occidental — manifestaba el citado autor - la palabra ley ha denotado siempre (...) una posición de superioridad, la procedencia de quien ostenta el poder el poder supremo en la comunidad $\gg 59$.

\footnotetext{
59 Cfr. Derecho Constitucional. Sistema de fuentes, Barcelona, Ariel, 1987, p. 103.
} 
Tales principios habían sido asumidos por la Constitución francesa de 1791 que afirmaba diáfanamente la supremacía de la ley cuando negaba que hubiera en Francia autoridad superior a la misma ${ }^{60}$, de igual modo que, tras identificar a la Nación con la depositaria de la soberanía ${ }^{61}$ y delegar el ejercicio de la potestad legislativa en la Asamblea $\mathrm{Nacional}^{62}$, asignaba a los decretos dictados por el Cuerpo legislativo fuerza de ley, así como el título y nombre de leyes ${ }^{63}$, reconociendo de este modo en la ley la acción procedente del detentador de la soberanía. Bien es verdad, con relación a este último asunto, que la misma disposición constitucional francesa que asignaba la potestad legislativa a la Asamblea Nacional, concedía también al rey la de sancionar las leyes, pero debe tenerse en cuenta que la contribución regia al perfeccionamiento de la voluntad parlamentaria con ser importante no era determinante, toda vez que la colisión entre ambas instancias se resolvía en favor del parlamento, como se sigue de lo que prevenía la disposición atributiva de fuerza de ley a los decretos del Cuerpo legislativo, en cuya virtud adquirían ese rango una vez sancionados por el rey o después de solicitarse, sin éxito, en tres legislaturas consecutivas su sanción.

La Constitución española de 1812 no fue ajena a los referidos planteamientos. A diferencia de la Constitución francesa de 1791 carecía, desde luego, de un pronunciamiento en el que explícitamente declarase la posición de superioridad de la ley sobre cualquier autoridad estatal, pero incluía el texto gaditano, en cambio, un conjunto de disposiciones que, interpretadas sistemáticamente, testimonian que la ley era considerada como la manifestación típica del sujeto representante de la soberanía en el Estado. Téngase en cuenta, de un lado, que si en virtud de lo dispuesto en el art. 3 la soberanía residía esencialmente en la Nación, el art. 27 confiaba a las Cortes su representación, y, de otro, que el art. 15, según se ha dicho ya, les encomendaba el ejercicio de la potestad legislativa. No pasamos por alto que la letra de la mencionada disposición convocaba al parlamento y a la corona a cooperar en la formación de la ley, ni que una interpretación de su dictado, conectada a los de otras disposiciones constitucionales avalan esa inferencia. Nos referimos a las que atribuían respectivamente a las Cortes las facultades de proponer, decretar, interpretar y derogar las leyes (art. 131.1) y al Rey las de iniciativa (art. 32) y sanción legislativa (art. 142), claramente reveladoras de que en un clima de entendimiento mutuo colaborarían sin duda las Cortes con el Rey en

\footnotetext{
${ }^{60}$ Título III, Capítulo 3, artículo $3^{\circ}$.

${ }^{61}$ Título III, artículo $1^{\circ}$.

62 Título III, artículo $3^{\circ}$.

63 Título III, Capítulo $3^{\circ}$, sección $3^{\mathrm{a}}$, artículo $6^{\circ}$.
} 
las tareas legislativas. Pero no debe olvidarse que en caso de discrepar ambas instancias terminaría prevaleciendo la opinión de las Cortes sobre la del monarca, pues, en virtud de lo previsto en los artículos 143 a 149 de la Constitución, después de que el rey se negase a sancionar un mismo proyecto de ley en dos ocasiones consecutivas, se entendía que otorgaba la sanción si por tercera vez lo aprobaban las Cortes.

\subsubsection{Igualdad de derechos e igualdad ante la ley}

De cuanto se ha venido diciendo se desprende, en definitiva, que la Constitución de 1812 no sólo identificaba a la ley con la expresión de la voluntad general, como hacía el art. 6 de la Declaración de derechos de 1789, sino también con la emanación del órgano representante de la soberanía estatal, con lo que esto último le comunicaba de aptitud para imponerse frente a cualquier otra manifestación de voluntad que pudieran exteriorizar los restantes poderes del Estado. Ahora bien, en nada podían contribuir tales atributos de la ley a que ésta fuese la misma para todos protegiese o castigase, como demandaba además el art. 6 de la citada Declaración francesa. Eso dependía de otra circunstancia, de la firme determinación por eliminar el obstáculo que podía impedirlo, es decir, los privilegios por razón de nacimiento. Sólo así lograría satisfacer la ley esa vocación de aplicarse universalmente. Conviene tenerlo en cuenta como también que la Constitución de 1812 no ignoraba este segundo aspecto de los planteamientos de Rousseau en torno a la ley que asumía la Declaración de Derechos de 1789 en los términos que expresaba su art. 6. No se olvide que ya en el Discurso Preliminar al Proyecto constitucional de Cádiz, se decía sobre este particular que si bien en un Estado libre algunas personas podían no concurrir a la formación de las leyes, no les era dado a éstas establecer diferencia ninguna de condición ni de clases entre los individuos de dicho Estado. «La ley ha de ser una para todos y en su aplicación no ha de haber acepción de personas», recuérdese que apostillaban a este respecto los redactores del Discurso Preliminar.

Por consiguiente, no extraña en absoluto que la Constitución de $1812 \tan$ sólo concediese a los ciudadanos el derecho a participar en los asuntos públicos y asignase, en cambio, a todos los españoles la titularidad de los derechos civiles que consagraba, como era de esperar por el modo en que se desarrollaron los debates constituyentes y se desprende de lo que disponía, particularmente, en su art. 4 - de idéntica redacción a la del art. 5 del Proyecto-y en cuya virtud estaba obligada la Nación «a conservar y proteger por leyes sabias y justas la libertad civil, la propiedad y los demás derechos legítimos» de los españoles. 
Excluidos los políticos había de entenderse, en efecto, referida a los derechos civiles la invocación que hacía el artículo a los derechos legítimos, como por cierto, sugería ya la naturaleza de los que mencionaba expresamente, la propiedad y la libertad civil, y parecía confirmar el que luego, al regular el art. 287 una de las manifestaciones de esa libertad civil, la de los casos y formas en que cabía la prisión, emplease la expresión «ningún español» para amparar a todos con las garantías que contemplaba. Otra cosa es que para el art. 371 «todos los españoles» fuesen también los destinatarios de un derecho tan difícil de categorizar como el de la libertad de «escribir, imprimir y publicar» las ideas políticas.

No se olvide tampoco que para la Comisión debía considerarse comprendida la igualdad legal entre los derechos legítimos de los españoles a que apelaba el art. 4 de la Constitución en su inciso final y que, de ser así, también estaría obligada la Nación a conservarla y protegerla por leyes sabias y justas. Con todo, la pretensión de vincular la acción del legislador a la procura del objetivo señalado no prosperaría si quien era convocado al efecto no asumía el encargo constitucional y efectivamente actuaba en tal sentido, sin que además hubiese de rendir luego cuentas de su proceder, por lo impracticable de las vías que hubiesen podido utilizarse para reconducir a la constitucionalidad las disposiciones legislativas que contrariasen aquella previsión. En otros términos, aunque existían mecanismos constitucionales que, desde una perspectiva actual, se nos antojan susceptibles de haberse empleado para reaccionar frente a tales leyes, no se pensó, sin embargo, entonces en darle ese uso. Nos referimos a la figura de las infracciones de la Constitución de 1812 prevista en su articulado, cuya concreta configuración aclara lo que intentamos expresar. Inmediatamente nos ocuparemos de ella, no sin antes advertir que ha sido estudiada por Marta Lorente con tanto rigor y exhaustividad que, desde ahora, nos remitimos a su trabajo para completar la información que aquí ofrecemos acerca de la misma, guiados del propósito de no aludir sino a los aspectos más sobresalientes de la institución.

\subsubsection{Referencia al instituto de las infracciones de la Constitución}

En lo que se refiere a su regulación constitucional debe tenerse en cuenta, en primer lugar, que, según disponía el art. 372, las Cortes habían de tomar en consideración «las infracciones de la Constitución que se les hubieren hecho presentes, para poner el conveniente remedio y hacer efectiva la responsabilidad de las que hubieren contravenido a ella». Además ha de reseñarse, en segundo lugar, que, conforme a lo dispuesto en el art. 373, todo español tenía derecho a dirigirse ante las Cortes o el Rey para reclamar la observancia de la Constitución. En cuan- 
to al procedimiento propiamente dicho nada prevenía la Constitución, fue configurado después de las sucesivas medidas que al respecto adoptaron las Cortes. En su virtud, una vez que recibieran la oportuna representación examinarían si el caso denunciado entrañaba o no una auténtica vulneración de la Constitución y decretarían, en caso afirmativo, la apertura de la causa, de la que conocerían los tribunales de justicia ${ }^{64}$. Suficientemente significativo de la importancia que concedían las Cortes a este asunto son los términos literales de su Decreto de 28 de noviembre de 1812:

«Las Cortes generales y extraordinarias, convencidas de la necesidad y utilidad de que los expedientes sobre infracción de la Constitución sean tramitados por la mayor prontitud posible, decretan: Los Tribunales del Reino preferirán a todo otro asunto los relativos a infracción de la Constitución política de la Monarquía» ${ }^{65}$.

Confirmaba así el Decreto en cuestión lo que de suyo se deducía de las disposiciones constitucionales anteriormente citadas, esto es, que la Constitución de 1812 tenía cuando menos vocación de aplicarse directamente ${ }^{66}$, con lo que eso significaba de garantía para los derechos contemplados en su art. 4 y la igualdad ante la ley que, a pesar de no mencionarla expresamente la disposición, la entendieron los españoles implícitamente enunciada en su dictado, como lo evidencian las denuncias recibidas en las Cortes de habérsela quebrantado y que relaciona Marta Lorente en su obra ${ }^{67}$.

La institución, en resumidas cuentas, resultó ser en su época un instrumento de reacción ante infracciones constitucionales supuestamente cometidas por los poderes ejecutivo y judicial, pero no llegó a mostrarse en otra faceta para la que, desde una perspectiva actual, se revelaba también útil, es decir, como mecanismo con que hacer frente a las leyes contrarias a la Constitución; pues, como ha señalado Marta Lorente, en ningún momento se cuestionaron las Cortes si su pro-

64 Para una mayor información sobre el procedimiento que, en su mayor parte, discurría por cauces judiciales, de las distintas regulaciones que recibió en el tiempo, así como de las facultades residuales que al respecto conservaron las Cortes. Cfr. Marta Lorente Sariñena. Las infracciones a la Constitución de 1812, Madrid, C.E.C., 1988, pp. 61 a 99.

${ }_{65}$ De este Decreto tenemos noticias por Fairen Guillen. Cfr. «La Constitución como norma jurídica de aplicación directa (en España, desde 1812)», en Estudios de Derecho Procesal Civil, Penal y Constitucional, Madrid, EDERSA, 1984, p. 13.

${ }^{66}$ Según Fairen Guillen, «en 1812 se producía en España el primer caso de pretensión de aplicarse directamente la Constitución; cfr. La Constitución como norma jurídica de aplicación directa (...), cit. p. 14. Mientras que para Marta Lorente «la conceptualización de la Constitución de 1812 como norma suprema obligó a garantizar jurídicamente su cumplimiento, su aplicación por los poderes encargados de ponerla en planta»; cfr. Las infracciones a la Constitución de 1812, cit. p. 29.

${ }^{67}$ Cfr. Las infracciones a la Constitución de 1812, cit. pp. 206 y 207. 
ducción legislativa vulneraba el texto constitucional ni, por tanto, se plantearon tampoco la posibilidad de enjuiciar la constitucionalidad de las leyes ${ }^{68}$.

\subsubsection{Codificación y unidad jurisdiccional}

Sea como fuere, contribuiría el art. 4 a que la ley fuese una para todos y en su aplicación no hubiese acepción de personas. Pero también otras previsiones constitucionales propendían a ese objetivo que describió la Comisión en su Discurso Preliminar al Proyecto de Constitución. Ese era el caso de las ya conocidas formulaciones, de alcance más concreto y específico, que incluían los artículos 247 y 257 del Proyecto al fuero único y el plan codificador, no en balde consideradas en el debate constituyente manifestaciones de la igualdad legal implícitamente proclamada en el art. 5 del Proyecto y que terminaron recogiendo los artículos 248 y 258 de la Constitución. Pues, sin duda alguna, favorecían la aplicación igual del derecho sus respectivas pretensiones de igualdad jurisdiccional y de establecimiento de un marco normativo homogéneo para toda la $\mathrm{Na}$ ción, y son conceptuables, por tal motivo, como medidas complementarias de lo que disponía el art. 4 de la Constitución.

\subsubsection{Los deberes de los españoles. En especial, la obligación de contribuir}

Casi a continuación del peculiar tratamiento que concedía a los derechos el art. 4 de la Constitución, se ocupaba ésta de los deberes a que aludíamos más arriba. Sólo el art. 5, dedicado a definir quienes eran españoles —en idénticos términos que el art. 6 del Proyecto-, separaba a una y otra regulación, con el efecto subsiguiente de convertir a los españoles en destinatarios de tales obligaciones, que recuerdan a las enumeradas en la Declaración francesa de los Derechos y de los Deberes de los ciudadanos de 1795. Sus determinaciones influyeron, sin duda, en el tono marcadamente genérico e indeterminado de los deberes enunciados en el art. 6 de la Constitución española que «en el amor a la patria» identificaba «una de las principales obligaciones de todos los españoles», aunque no la única, pues concedía la misma importancia a la de ser «justos y benéficos». Paralelamente el art. 7 de la Constitución de 1812 recibió una redacción que recuerda a la del art. 3 de la referida Declaración francesa, si bien la versión española parece más completa. En su virtud, «todo español estaba obligado a ser fiel a la Constitución», obedecer las leyes y respetar las autoridades establecidas.

\footnotetext{
${ }^{68} \mathrm{Al}$ menos las postconstitucionales. Cfr. Ibíd. pp. 325 y ss.
} 
Los artículos 8 y 9 cerraban el conjunto de disposiciones concernientes a las obligaciones de los españoles con sendos llamamientos a sus deberes de contribuir y de defender a la patria con las armas. Prescindiendo de éste último, no está de más subrayar que la regulación constitucional española de lo tributario se integraba en el contexto que se ha venido describiendo de disposiciones caracterizadas por su homogeneidad temática, a diferencia del modelo francés de 1795 que abordaba este asunto con arreglo a otra sistemática. En otro orden de cosas, quizá sea la concisión la nota que mejor define el modo que tenía de enunciar la obligación el referido art. 8. Según disponía éste, también estaba sujeto todo español, «sin distinción alguna, a contribuir en proporción de sus haberes para los gastos del Estado». Los términos en que la obligación era descrita permiten identificar a quienes contribuirían con la misma facilidad que al principio vertebrador del sistema tributario, definido por la capacidad económica de los contribuyentes a que apelaba el criterio de la proporcionalidad invocado en el art. 8. El equilibrado reparto de la carga impositiva por el que se pronunciaban las Cortes constituyentes a través de dicha disposición es merecedor de un último comentario. Como las diferentes previsiones constitucionales francesas de 1791, 1793 y 1795, de análogo contenido, era la manifestación en ese terreno de lo tributario de la igualdad legal o de derechos implícitamente proclamada por la Constitución de 1812.

\subsection{El Proyecto de Código Civil de 1821}

En el curso de los debates constituyentes Pérez de Castro aludió claramente a una relación de colaboración funcional entre Constitución y ley o, mejor, entre Constitución y códigos, de naturaleza jerarquizada, que nos indujo a considerarlo consciente de participar en la cimentación de un edificio que si descansaba en la Constitución terminaría de levantarse con ayuda de los códigos a que se refería, complementarios de sus previsiones relativas a los derechos civiles.

Además, como hemos dicho también, quizá los postulados del Código Civil francés de 1803 pudieran haber inspirado, cuando menos en parte, el tratamiento que, a instancias de la Comisión de Constitución, concedieron las Cortes de Cádiz a los derechos en el art. 4 de la Constitución. No es imposible, en efecto, que una vez definido el «status» de ciudadano y regulados los derechos políticos que, como a tales les correspondían, pensaran los miembros de la citada Comisión, dejándose llevar por las previsiones de los artículos 7 y 8 del Código Civil francés, que la regulación de los derechos civiles cuya titularidad reconocían a todos los españoles, era un asunto del que debía ocuparse el futuro Código Civil, bastando a nivel constitucional con recordar su existencia del modo en que lo hacía el citado art. 4. 
Sea como fuere, la Comisión Especial de las Cortes que, por su encargo redactó entre 1820 y 1821 el Primer Proyecto de Código Civil, prestó una enorme atención a los derechos civiles. Baste señalar al respecto que tras destinar el Título Preliminar a las leyes en general, dedicó toda su Primera Parte, compuesta de tres libros y veintiún títulos a tales derechos, si bien es verdad que tan extenso tratamiento abarcaba lo que hoy llamaríamos los derechos de familia y de propiedad. Sus trabajos estuvieron presididos por el principio de subordinación del futuro Código a la Constitución, cuyas pretensiones pretendía desarrollar según explicaba en el Discurso Preliminar que acompañó al texto articulado del Proyecto, en donde, al exponer dichas ideas, ofrecería un concepto de Constitución muy próximo al del art. 16 de la Declaración francesa de los Derechos del Hombre y del Ciudadano de 1789. Gracias al «derecho constitucional», sostenía la Comisión que adquiría una sociedad su organización, por él, decía, «se establecen las relaciones de todos los individuos de una Nación; y se da existencia a los poderes encargados de ejercer las partes integrantes de su esencial soberanía; a sus jerarquías, y a los derechos y obligaciones de cada uno de sus miembros. En el orden social no existen derechos ni obligaciones sino por disposición de la ley (...). Es pues la ley, y sólo ella, la que da vida a los derechos y a las obligaciones; y cuando prescribe estos derechos y obligaciones en grande, esto es, de la sociedad para con todos sus individuos, y al contrario, se llama propiamente ley fundamental. De ella se derivan y son emanaciones suyas, las leyes que podrían llamarse secundarias, y que forman la materia de los diferentes códigos acordados por las Cortes $(. ..){ }^{69}$.

Pero aunque la Comisión no albergaba dudas respecto a que el desarrollo de la Constitución resultaría de la acción concertada de los diferentes códigos no les concedía a todos el mismo valor, toda vez que entendía subordinados al Código Civil los de comercio, de procedimientos y el mismo Código Penal al que consideraba «secuela de los códigos constitucional y civil ${ }^{70}$. En esa supremacía del

69 Juan Francisco Lasso Gaite: Crónica de la Codificación española. 4. Codificación Civil, vol. II, Madrid, Ministerio de Justicia, 1970, p. 8.

${ }^{70}$ Cfr. Ibíd. p. 9. A una interpretación como esa se prestaba desde luego el siguiente pasaje, algo ambiguo, del Discurso Preliminar al Proyecto de Constitución: «Como toca a la Constitución determinar el carácter que ha de tener en una nación el código general de sus leyes positivas, deben establecerse en ellas los principios de que han de derivarse aquellas y cualesquiera otras disposiciones, que bajo el nombre de ordenanzas o reglamentos hayan de dirigir las transacciones públicas y privadas de los individuos de una nación entre sí, o las que celebren con los súbditos de otros estados con quienes puedan entablar comunicación. Estas reglas no sólo han de servir para la formación de nuevas leyes, sino para dirigir a las Cortes en la derogación o reforma de las que sean incompatibles con el nuevo sistema planteado por la Constitución. Cfr. Sevilla Andrés Constituciones y otras leyes y proyectos políticos de España, vol. I, cit. p. 137. 
Código Civil sobre los restantes y en el criterio de la especialización material con arreglo al cual entendía la Comisión que debían delimitarse sus respectivos contenidos debe buscarse la razón de que el Proyecto de Código Civil de 1821 casi redujese su objeto al tratamiento de los derechos civiles, como además reconocía la Comisión en su Discurso Preliminar:

«El Código Civil no es otra cosa más que el desenvolvimiento de los artículos $4,6,7,8,9,12,15,16$ y 17 de la Constitución.

El primero de ellos versa sobre los derechos y obligaciones individuales, y constituye la parte primera del Código. Los restantes en su totalidad pertenecen a la administración general del Estado, aunque para ella se exijan ciertas obligaciones de los individuos. El orden mismo de la Constitución dio la preferencia de lugar a las materias que se comprenden en esta primera parte» ${ }^{71}$.

Todavía tuvo oportunidad la Comisión de manifestarse en su Discurso Preliminar con algo más de detenimiento sobre la anunciada implementación de las disposiciones constitucionales citadas, mediante una declaración, por eso mismo complementaria de la anterior, destinada a informar respecto al alcance de su propuesta en este sentido. Pues bien, esa declaración que ahora comentamos incluía un pronunciamiento a propósito de la distinción entre los derechos políticos y los civiles, así como sobre sus recíprocas posibilidades de desarrollo legislativo - de acuerdo con el tratamiento que respectivamente recibiesen en la Constitución, cualquiera que fuese ésta-, que recuerda el planteamiento de los artículos 7 y 8 del Código Civil francés de 1803:

«La ley crea los derechos e impone las obligaciones. Los derechos y las obligaciones que dimanan inmediatamente de la ley fundamental se llaman políticos y se hallan marcados en la misma. Las leyes secundarias podrían dar alguna explicación para hacerlos efectivos, pero sin desviarse de manera alguna de su base. El objeto inmediato de estos derechos y obligaciones es sostener el Estado y aumentar su prosperidad. Hay otra clase de derechos que emanan de la ley fundamental para el bienestar individual de cuantos componen el Estado mismo, y que podrían llamarse civiles. El art. $4^{\circ}$ los enumera así: 'libertad civil, propiedad y demás derechos legítimos'. La Comisión se consideró obligada a expresar en grande la índole, extensión y duración de estos derechos, para tener una base segura sobre la cual pudiese en las restantes partes del Código llevar a debido cumplimiento lo ofrecido en dicho art. $4^{\circ}$; a saber, que se protegerán con leyes sabias y justas los derechos expresados ${ }^{72}$.

${ }^{71}$ Cfr. Crónica de la Codificación española, cit. p. 16.

${ }^{72}$ Cfr. Ibíd. p. 16. 
El objetivo prioritario de la Comisión era, en definitiva, completar el escueto listado de derechos expresamente mencionados en el art. 4 de la Constitución, aprovechando al efecto las posibilidades que ofrecía su inciso final. De este asunto se ocupó en el primer párrafo de los dos con que dotó al 34 del Proyecto, enseguida veremos cómo. Antes conviene precisar que la solución propuesta se enmarcaba en un contexto de ideas más amplio e inspirado, a su vez, en el modelo de relación entre Constitución y Código Civil descrito en los artículos 7 y 8 del Código napoleónico, como por cierto era de esperar después de lo que se sugería en el pasaje del Discurso Preliminar más arriba transcrito. Así se desprende con toda claridad de lo dispuesto en el párrafo segundo del art. 34 del Proyecto, en virtud del cual «los derechos políticos de los españoles como ciudadanos se hallan determinados por la Constitución» ${ }^{73}$. En el párrafo primero, en cambio, la Comisión acometió la anunciada concretización de la fórmula con que concluía el art. 4 de la Constitución. Su intención era equiparar la libertad civil y la propiedad con la seguridad individual y la igualdad legal. No en balde, allí eran citadas por este orden y calificadas, acto seguido, sin excepción alguna, como «los principales derechos legítimos de los españoles» ${ }^{74}$. El dato revela además que no pretendía la Comisión imprimir a su tarea carácter exhaustivo, que no buscaba agotar en el referido párrafo primero del art. 34 el repertorio de los posibles derechos legítimos de los españoles, como por otro lado confirma el que luego dispusiera el art. 52 que, en general, eran tales los autorizados por la ley. La enumeración que, a título ejemplificativo, asimismo incluía la disposición nos parece elocuente del extenso significado que le concedía la Comisión al concepto, adecuado para describir «la patria potestad, la tutela, y otros semejantes; los que habilitan para ejercer cargos públicos o para otros actos civiles, como testar, contratar, comparecer en juicio, adquirir o transmitir bajo las ampliaciones o modificaciones que prescribe la ley» ${ }^{75}$.

Por cuanto se ha venido diciendo no cabe ninguna duda de que la Comisión pretendió subsanar la omisión del art. 4 de la Constitución acerca de la igualdad. A ese objetivo respondía el enunciado del art. 34 del Proyecto, en donde no sería calificada en vano como uno de los principales derechos legítimos de los españoles, pues luego volvería a ocuparse de la misma el art. 51, aunque sólo fuese para intentar definirla de la manera siguiente:

${ }^{73}$ Cfr. Ibíd. p. 31.

${ }_{74}$ Cfr. Ibíd.

${ }^{75}$ Cfr. Ibíd. p. 32. 
«Todos los españoles son iguales ante la ley para reclamar derechos y cumplir obligaciones, sin diferencia de nacimiento, de calidad o de fortuna. Esta igualdad constituye el derecho que se llama igualdad legal» ${ }^{76}$.

Conviene tener presente que el citado artículo 51 se ubicaba entre los integrantes de la Primera Parte del Proyecto, significativamente rotulada: «De los derechos y de las obligaciones individuales». Constaba esta Primera Parte de dos libros de los cuales sólo aludiremos aquí al Primero para señalar que llevaba por rúbrica «de los derechos y obligaciones de los españoles en general» y que lo integraban siete títulos. Uno de ellos acogía la proclamación de la igualdad ante la ley del art. 51, concretamente el Título I, del que tampoco omitiremos cual era su encabezamiento: «De la naturaleza de los derechos y de las obligaciones», pues como los de las anteriores divisiones del Proyecto revela el enorme interés que mostraron sus autores por los derechos individuales. A regularlos atendía preferentemente el documento que, sin embargo, no se limitaba a eso, pues se ocupaba además y detenidamente, por cierto, de la ley en su Título Preliminar. En otros términos, los derechos y la ley resultaban ser los únicos contenidos del Proyecto de Código Civil, en cuyo preámbulo adelantaban ya sus redactores que también las previsiones constitucionales referentes a la ley requerían de ulteriores precisiones por el futuro cuerpo normativo, coherentemente con la condición de complemento directo e inmediato de la Constitución que genéricamente le asignaban. Como en otras ocasiones, preferimos transcribir las palabras de la Comisión a que nos referimos:

«Fijar la naturaleza y carácter de aquella disposición que se llama ley debía ser sin disputa el objeto primero del Código. La Comisión tuvo muy presente lo que la Constitución previene acerca del modo de formar, publicar y promulgar las leyes, pero sin apartarse de la letra y espíritu de los artículos que de ello tratan, creyó debía entrar en ciertos pormenores que son siempre materia de leyes secundarias; al modo que se ha practicado por medio de ellas con los artículos de la Constitución que hablan de la calidad de sirviente doméstico, del principio de conciliación, de la justificación previa a la captura, etc. Y en los mismos que prescriben todos los trámites para la formación de las leyes, es notorio que el reglamento interior pudo y debió hacer algunas declaraciones. Faltaba además prescribir reglas para la observancia de las leyes; y estos son los puntos de que trata el título preliminar. La Comisión juzga superfluo observar que las disposiciones de sus artículos son comunes a todos los códigos acordados ya o que se acordaren, y extensivas a las leyes transitorias o momentáneas; a no ser que en ellas se fije la

${ }^{76}$ Cfr. Ibíd. 
época desde la cual empiezan a tener vigor, o el período o la localidad a que se extiende su duración u observancia» ${ }^{77}$.

Nos apartaría demasiado del objetivo que nos hemos trazado prestarle la atención que merece al minucioso tratamiento que le dedicaba a la ley el Título Preliminar del Proyecto de Código Civil. En efecto, bien por la especial tarea que con él consideraban estar realizando sus autores, el desarrollo directo de las determinaciones constitucionales al que debían subordinarse los restantes códigos, o bien porque previesen la necesidad de adoptar futuras leyes complementarias de éstos, el caso es que ofrecía el Proyecto, en el lugar indicado, una pormenorizada regulación de la ley que reclama un análisis más detenido del que se le dará. A los efectos que aquí se persiguen sólo son relevantes algunas de sus formulaciones, como es el caso de la que albergaba el art. $1^{\circ}$ confirmatoria de la conclusión a que llegábamos tras analizar el sistema electoral previsto en la Constitución, es decir, que en su virtud la ley alcanzaba a ser la expresión de la voluntad general. No en balde, disponía textualmente aquel artículo: «la ley es la voluntad de todos los españoles de ambos hemisferios expresada por medio de sus legítimos representantes y corroborada por la sanción del Rey con arreglo a la Constitución ${ }^{78}$. También interesa subrayar que el Proyecto de Código Civil reproducía en su Título Preliminar el principio según el cual la ley debía ser considerada igual para todos, que advertíamos enunciado tanto en el art. 6 de la Declaración de Derechos francesa de 1789, como en el Discurso Preliminar al Proyecto constitucional de Cádiz, y que venimos entendiendo en el sentido de presumir a la ley aplicable con carácter general, sin excepciones. Así cabe sostenerlo en base a lo que prevenían los artículos 14 y 24 del Proyecto, pues si el primero contemplaba la posibilidad de que las Cortes pudieran «conceder la dispensa de una ley», señalando qué procedimiento había de seguirse al efecto ${ }^{79}$, pocas dudas suscita el tenor literal del segundo sobre su significado y alcance: «las leyes solemnemente promulgadas obligan a todos sin distinción alguna» ${ }^{80}$.

Teniendo en cuenta que las Cortes no aprobaron el Proyecto de Código Civil, la conclusión a cuanto se viene diciendo casi se impone por sí misma. Con ello no sólo se perpetuaba la indefinición de que adolecía el art. 4 de la Constitución en su inciso final, sino también y principalmente se impedía el cumplimiento del plan trazado por el constituyente acerca de la igualdad ante la ley. No se olvide

77 Cfr. Ibíd. p. 16.

78 Cfr. Ibíd. p. 28.

79 Cfr. Ibíd. p. 29.

${ }^{80}$ Cfr. Ibíd. p. 24. 
a este respecto que la Comisión de Constitución, en el Discurso Preliminar a su Proyecto, manifestó que la codificación era el instrumento elegido para la puesta en práctica, «en toda la extensión de la monarquía», de la uniformidad de principios en que basaba la ley fundamental. En definitiva, de haberse aprobado hubiese desempeñado el Código Civil la misión que constitucionalmente se le encomendaba. Su vocación de cuerpo normativo unitario y único del ámbito de la realidad a que atendía su proyecto le confería la misma característica que a los restantes de su especie, con los que estaba llamado a realizar el plan codificador de la Constitución, esto es, la de ser presupuesto de la igualdad ante la ley.

Title:

\section{SPANISH AND CITIZENS BEFORE THE LAW AND THE CONS- TITUTION OF 1812}

\section{Summary:}

1. The preliminaries: The installation of the Courts and its decree of September 24, 1810. 2. Equality in the Draft Constitution. 2.1. The creation of the Committee on Constitution and its initial position with respect to equality. 2.2. The agreement of April 10, 1811. 2.3. The final proposal on equality. Arrangements 7 and August 8, 1811. 3. The phased development of the Draft Constitution. Phases. 3.1. The two «first part» of the Draft Constitution. Their debate in plenary. 3.1.1. The discussion about the art. 5. 3.1.2. The controversy over caste. 3.2. The second installment of the Preliminary Statement and the Constitution proyect. 3.2.1. Equality before the law in the Preliminary Statement. 3.2.2. Unit of jurisdiction and the coding will draft Constitution. 4. The solution adopted constitutionally. 4.1. Slaves, freedmen, freemen and citizens. 4.2. Equality before the law. 4.2.1. About the law and its constitutional conceptualization. 4.2.2. Equal rights and equality before the law. 4.2.3. Reference to institute infringement of the Constitution. 4.2.4. Coding and jurisdictional unity. 4.2.5. The duties of the Spanish. In particular, the obligation to contribute. 4.3. The draft Civil Code of 1821.

\section{Resumen:}

Este trabajo hace un seguimiento del tratamiento dado a la igualdad por las Cortes de Cádiz desde el trascendental Decreto de 24-IX-1810 hasta el Proyecto de Código Civil de 1821, pasando por todas las fases de elaboración de la Constitución. Se pone de relieve dos corrientes de opinión que sobre la igualdad había en las Cortes y el debate acerca de si la 
igualdad era un derecho o un modo de ejercicio y disfrute de los derechos y de administración de la justicia. Se analiza la incidencia del problema de las castas en este debate, con el resultado final de la distinción entre esclavos, libertos, hombres libres y ciudadanos. La última parte del trabajo está dedicada a la igualdad ante la ley y a los deberes de los españoles, así como a la relación entre igualdad y codificación y de la administración de justicia.

\begin{abstract}
:
This paper tracks the equal treatment of the Courts of Cadiz from the momentous decree of 24-IX-1810 to the Civil Code Project, 1821, through all stages of drafting the Constitution. It highlights two schools of thought on equality that had in the courts and the debate about whether equality was a right or a mode of exercise and enjoyment of the rights and administration of justice. We analyze the incidence of the problem of caste in this debate, with the final result of the distinction between slaves, freedmen, freemen and citizens. The last part of the work is dedicated to equality before the law and the duties of the Spanish, as well as the relationship between equality and coding and administration of justice.
\end{abstract}

\title{
Palabras clave:
}

Igualdad, libertad, derechos, Constitución, codificación, ley.

\section{Key words:}

Equality, freedom, rights, Constitution, code, law. 